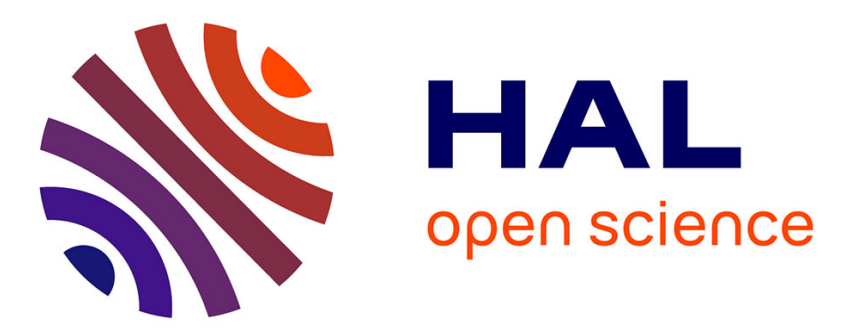

\title{
Paleoproterozoic tectonic evolution of the Trans-North China Orogen: toward a comprehensive model.
}

\author{
Pierre Trap, Michel Faure, Wei Lin, Nicole Le Breton, Patrick Monié
}

\section{To cite this version:}

Pierre Trap, Michel Faure, Wei Lin, Nicole Le Breton, Patrick Monié. Paleoproterozoic tectonic evolution of the Trans-North China Orogen: toward a comprehensive model.. Precambrian Research, 2012, 222-223, pp.191-211. 10.1016/j.precamres.2011.09.008 . insu-00628119

\section{HAL Id: insu-00628119 \\ https://hal-insu.archives-ouvertes.fr/insu-00628119}

Submitted on 2 Jan 2012

HAL is a multi-disciplinary open access archive for the deposit and dissemination of scientific research documents, whether they are published or not. The documents may come from teaching and research institutions in France or abroad, or from public or private research centers.
L'archive ouverte pluridisciplinaire HAL, est destinée au dépôt et à la diffusion de documents scientifiques de niveau recherche, publiés ou non, émanant des établissements d'enseignement et de recherche français ou étrangers, des laboratoires publics ou privés. 


\title{
Paleoproterozoic tectonic evolution of the Trans-North China Orogen: Toward a comprehensive model
}

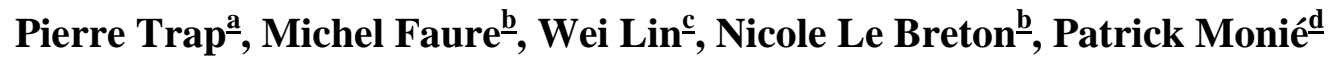

a UMR-CNRS 6249 Chrono-Environnement, Université de Franche-Comté, 16 route de Gray 25030 Besançon Cedex, France

b Institut des Sciences de la Terre d'Orléans, CNRS, Université d'Orléans (UMR 6113), 45071 Orléans Cedex 2, France

c State Key Laboratory of Lithosphere Evolution, Institute of Geology and Geophysics, Chinese Academy of Sciences, Beijing 100029, China

d Géosciences Montpellier, UMR CNRS 5243, Université Montpellier II, 34095 Montpellier Cedex 5, France

\begin{abstract}
In this contribution we present a reconstruction of the overall lithotectonic architecture, from inner zones to external ones, of the Paleoproterozoic Trans-North China Orogen, within the North China Craton. Moreover, forward thermobarometrical modelling on a kyanite-bearing gneiss yields a reliable prograde $\mathrm{P}-\mathrm{T}-\mathrm{t}-\mathrm{D}$ path. In addition, ${ }^{40} \mathrm{Ar} /{ }^{39} \mathrm{Ar}$ dating on rocks from distinct litho-tectonic units helps us to distinguish several tectono-metamorphic events during the orogenic development. Considering these results, we propose a geodynamic model involving three cratonic blocks, namely the Western, Fuping and Eastern Blocks, separated by two oceans, the Lüliang and Taihang Oceans. The opening of oceanic basins occurred around 2.2-2.3 Ga. After the westward subductions of oceanic lithosphere, the Trans-North China Orogen was built up through a polyphase tectonic evolution within the period 1900-1800 Ma. The first event (D1) corresponded to the emplacement of lower and upper nappes herein called the Orthogneiss-and-Volcanite Unit (OVU) and the Low-Grade-and-Mafic Unit (LGMU), respectively. The syn-metamorphic D1 deformation $(1880 \pm 10 \mathrm{Ma})$ is characterized by a NW-SE stretching and mineral lineation with a top-to-the SE sense of shear. During ongoing compression of the thickening orogenic crust, a second deformation event D2 (1850 $\pm 10 \mathrm{Ma}$ ) was responsible for (1) syn-anatectic lateral flow and exhumation of the orogenic root and (2) folding of the middle and upper parts of the orogenic wedge that consequently acquired a fan-type geometry. The late D3 (1830 $\pm 10 \mathrm{Ma})$ and D4 (1810 \pm 10 $\mathrm{Ma}$ ) events are related to late-orogenic normal and strike-slip shearing, respectively. In our present state of knowledge, the Paleoproterozoic Trans-North China Orogen might be regarded as the assemblage of two continent-continent collisional belts, both of which are characterized by nappe stacking accommodated by top-to-the E/SE ductile shearing. Continental subduction, crustal thickening, partial melting of overthickened crust, exhumation of HP rocks and deposition of syn-orogenic detrital basins are typical features of modern collisional-type orogens.
\end{abstract}

Keywords: Trans-North China Orogen; Paleoproterozoic; Collision; Pseudosection; ${ }^{40} \mathrm{Ar} /{ }^{39} \mathrm{Ar}$ dating; North China Craton 


\section{Introduction}

In response to lithospheric plate mobility through Earth history, continental collision is a major process that marks the periodic welding of continental masses to form supercontinents. Recently, the advances in discovering ancient orogens have led to the recognition of the Columbia supercontinent, which resulted from amalgamation of Paleoproterozoic and Archean blocks, during a wide 2.1-1.8 Ga orogenic period ( [Rogers and Santosh, 2002] , [Rogers and Santosh, 2009], [Zhao et al., 2002a] and [Zhao et al., 2004a] ). The Paleoproterozoic seems to be a pivotal period during which the deformation modes in response to convergence evolved in time and space, due to difference of strength of the lithosphere (Cagnard et al., 2011). As a consequence, the Paleoproterozoic 2.1-1.8 Ga belts show a large variety of orogenic styles (e.g. Chardon et al., 2009). Overall, most of Paleoproterozoic orogenic zones were described as accretionary-type orogens, defined by important mantle-derived (juvenile) magmatism, weak lithosphere strength and no highpressure (HP) metamorphism ( [Cagnard et al., 2006] , [Cagnard et al., 2007] and [Cagnard et al., 2011] ). On the contrary, Paleoproterozoic continent-continent collisional orogens, involving rigid continental blocks, HP metamorphism without juvenile magmatism are rare. Barely half a dozen of studies on rocks that have undergone major burial in terms of eclogite facies and HP granulites during Paleoproterozoic were recorded around the globe (e.g. Collins et al., 2004).

Within the North China Craton, the Trans-North China Orogen (TNCO) is commonly acknowledged as a continent-continent collisional orogen (Zhao et al., 2001a) with the development of an orogenic wedge, made through nappe stacking with flat lying thrust faults ( [Faure et al., 2007] and [Trap et al., 2007] ). No juvenile crust appears to be synchronous with collision. Litho-tectonic units with different metamorphic characters can be individualized. In particular, a high-pressure unit with $\mathrm{HP}$ granulites and retrograded eclogites recorded $\mathrm{P}-\mathrm{T}$ conditions of $15 \mathrm{kbar}$ and $650^{\circ} \mathrm{C}$ ( [O’Brien et al., 2005] and [Zhao et al., 2000a] ).

Unlike many Paleoproterozoic orogens, the present significant relief (up to $3000 \mathrm{~m}$ elevation) due to the Cenozoic tectonics of the North China Craton, the low vegetation cover and the limited weathering of outcrops allow to easily understand the 3D geometry of the geological structures and make the Trans-North China Orogen a very good natural laboratory for studying the behaviour of deep collisional orogenic crust. Therefore, a precise and valuable understanding of the tectonic evolution of the TNCO within the North China Craton is challenging, in order to bring new insights into the tectonic mechanisms, especially those occurring within the deep crust of collisional orogens.

In the last decades, a lot of work, with multidisciplinary approaches has increasingly been done on the TNCO. In particular, geochronological works provided more refinements of geological features of the TNCO. However, in spite of this huge dataset, no consensus has been reached, preventing any further discussion about implications for the global behaviour of continental lithosphere during Paleoproterozoic time. The main points of disagreement still disputed are: (i) the number and geometry of continental blocks that amalgamated along the TNCO to form the North China Craton; (ii) the number and polarity of subduction zones; (iii) the timing of TNCO collision and NCC amalgamation ( $\sim 2.5 \mathrm{Ga}$ vs. $\sim 1.85 \mathrm{Ga})$; (iv) the timing of tectonic events such as rifting, subduction and collision; (v) the type of orogen (accretionary-type vs. collisional-type orogen); (vi) the significance of the $\sim 1.85 \mathrm{Ga}$ metamorphism and (vii) the polyphase deformation between 1.9 and $1.8 \mathrm{Ga}$. 
In a first section of this contribution we present a brief summary of the geological features of the NCC, and the different tectonic models for the TNCO evolution that have been proposed until today. We then review the main lithological, structural, metamorphic and geochronological features of the TNCO. New petrological and ${ }^{40} \mathrm{Ar} /{ }^{39} \mathrm{Ar}$ geochronological data are also presented. Finally, the main disagreement points are discussed and a synoptic tectonic evolution model of the Trans-North China Orogen is proposed.

\section{Tectonic subdivision of the North China Craton}

\subsection{Cratonic blocks within the NCC}

The North China Craton consists of an Archean and Paleoproterozoic metamorphic basement overlain by a Mesoproterozoic unmetamorphosed sedimentary cover (Fig. 1). Commonly, a threefold subdivision of the NCC considers two main Archean blocks: the Western and Eastern Blocks (Zhao et al., 2005). More recently, refinements yield to the distinction of the Yinshan Block and the Ordos Block that collided to form the Western Block along the eastwest-trending Khondalite Belt ( [Santosh et al., 2007a] , [Santosh et al., 2007b] and [Zhao et al., 2005] ). This subdivision of the Western Block has led Santosh (2010) to reconsider the term "Eastern Block" as inappropriate and substituted it with "Yanliao Block". In the view of Faure et al. (2007) and [Trap et al., 2007] , [Trap et al., 2008] , [Trap et al., 2009b] and [Trap et al., 2011] , an intermediate fourth block is considered, the Fuping Block that lies between the Eastern and Western Blocks. More recently, Zhai and Santosh (2011) discuss a model on the amalgamation of seven micro-blocks, named the Jiaoliao (JL), Qianhuai (QH), Ordos (OR), Jining (JN), Xuchang (XCH), Xuhuai (XH) and Alashan (ALS) Blocks, to form that $\mathrm{NCC}$ at the end of Neoarchean. 


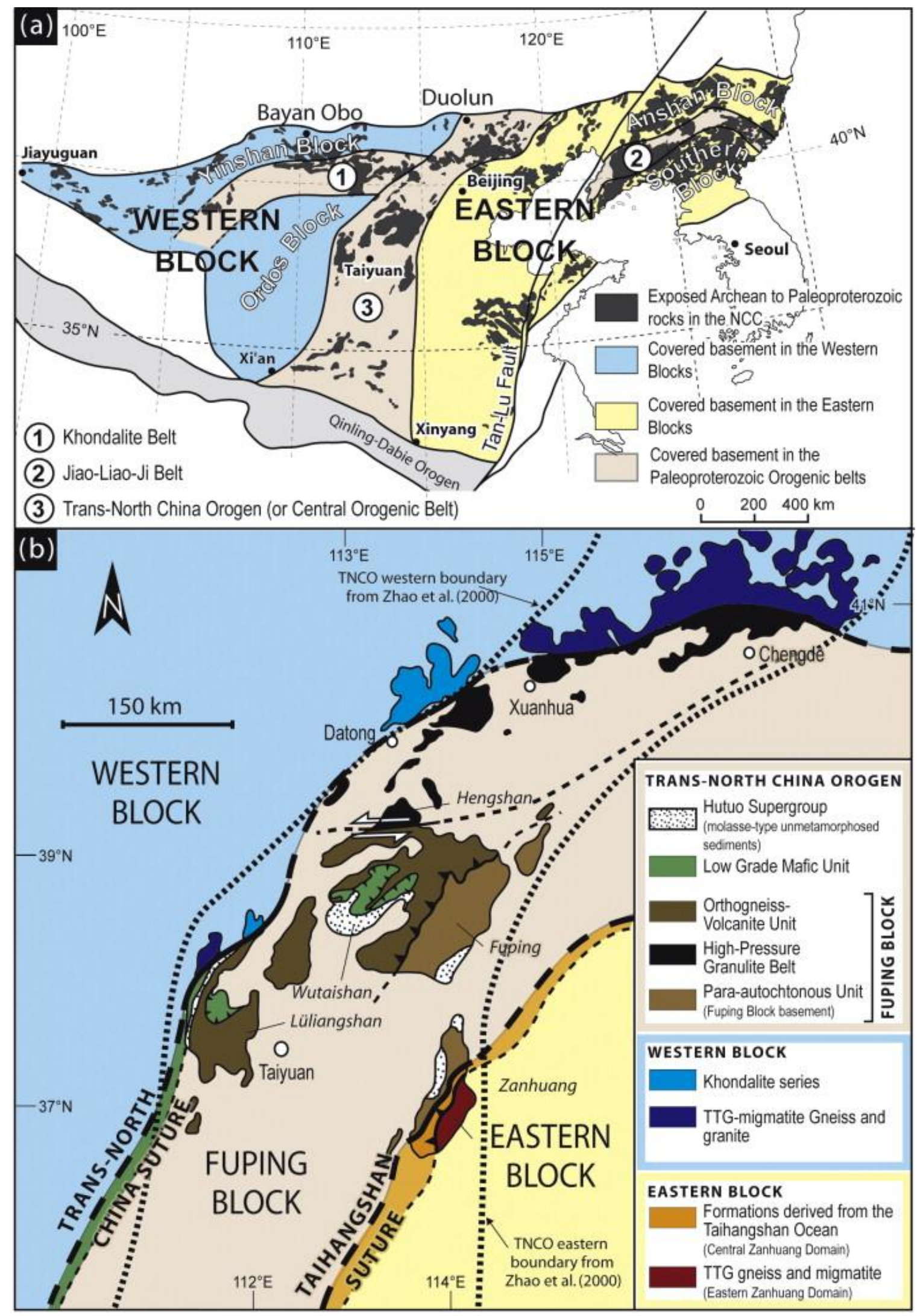

Fig. 1. : (a) Paleoproterozoic-Archean massifs of the North China Craton (NCC) and location of the Trans-North China Orogen (TNCO), and other belts: Khondalite Belt and Jiao-Liao-Ji Belt. (b) Lithotectonic map of the Trans-North China Orogen, with the threefold subdivision of the NCC, and the two suture zones as described in Faure et al. (2007) and [Trap et al., 2007] , [Trap et al., 2008] , [Trap et al., 2009a] and [Trap et al., 2009b] . First interpreted boundaries of the TNCO, from Zhao et al. (2000a) are represented as dashed line. 


\subsection{Orogenic belts within the NCC}

Three orogenic belts are documented within the NCC: (1) the Jiao-Liao-Ji Belt, (2) the Khondalite Belt and (3) the Trans-North China Orogen (TNCO).

The Jiao-Liao-Ji Belt is an E-W to NE-SW trending succession of sedimentary and volcanic rocks that have undergone metamorphism under greenschist and amphibolite facies conditions (Fig. 1; Zhao et al., 2005). The Jiao-Liao-Ji Belt could have formed through the opening of a continental rifting within the Eastern Block around $2100 \mathrm{Ma}$, associated with the deposition of sedimentary and volcanic rocks, and its subsequent closure around $1900 \mathrm{Ma}$ ( [Yang et al., 1988], [Li et al., 2005], [Li et al., 2006], [Luo et al., 2004], [Luo et al., 2008] and [Li and Zhao, 2007] ). A second model proposed a collision between two Archean continental blocks with the formation of a magmatic arc at $1900 \mathrm{Ma}$ ( [Bai, 1993], [Faure et al., 2004] and [He and Ye, 1998] ). According to Faure et al. (2004), the Jiao-Liao-Ji Belt was a mafic magmatic and sedimentary rocks belt that thrusts toward the North upon the northern Eastern Block (Anshan Block) and toward the South upon the Paleoproterozoic ( 2100 Ma) marble and volcanic rocks representing the former passive margin of the southern part of the Eastern Block (Southern Block). The Jiao-Liao-Ji Belt is not considered in models that discuss the final amalgamation of the North China Craton (e.g. Kusky et al., 2007). Indeed, it is difficult to extrapolate the westward extension of this belt, since it is interrupted by the Tan-Lu fault (Fig. 1).

The Khondalite Belt crops out from the Jining Mountains in the East, in the Daqingshan, Wulashan and Qianlishan massifs to the Helanshan Massif in the West (Fig. 1). It is regarded as the boundary between two Archean blocks, the Yinshan Block in the north and the Ordos Block in the south (e.g. [Zhao et al., 1999a], [Zhao et al., 1999b], [Zhao et al., 1999c] and [Santosh, 2010] ). As its name suggests, it is characterized by a large amount of khondalitic rocks made of garnet-sillimanite and garnet-quartz gneiss, which are considered as representing passive continental margin metasediments (Condie et al., 1992). Associated with Khondalites, there are few TTG gneisses and basic granulites, charnockites and S-type syntectonic granites (Santosh et al., 2007a). Protoliths ages range around 2.3-1.9 Ga whereas metamorphic ages vary from $2.0 \mathrm{Ga}$ to $1.9 \mathrm{Ga}$ ( [Wan et al., 2000], [Santosh et al., 2007a] , [Santosh et al., 2007b] , [Yin et al., 2009] and [Yin et al., 2011] ). HT-UHT metamorphism has been documented within the Khondalite Belt and occurred at $~ 1.92 \mathrm{Ga}$ ( [Santosh et al., 2006a] , [Santosh et al., 2006b] , [Santosh et al., 2007a] and [Santosh et al., 2007b] ).

The Trans-North China Orogen is the largest and best documented Paleoproterozoic belt within the NCC. It has been defined as a 200-300 km wide collisional orogenic zone that crosses through the NCC over $1200 \mathrm{~km}$ between the Eastern and Western Blocks ( [Wilde et al., 2002] , [Zhao et al., 1998] , [Zhao et al., 1999a] , [Zhao et al., 2000a] , [Zhao et al., 2001a] , [Zhao et al., 2004a] and [Zhao et al., 2004b] ). From north to south, the TNCO rocks crop out in the Chengde, Northern Hebei, Huai'an, Hengshan, Wutai, Fuping, Lüliang, Zanghuang, Zhongtiao, Dengfeng and Taihua Massifs (Fig. 1). The TNCO constitutes the main topic of this contribution and its geological features are described and discussed in the following.

\section{Current tectonic models for the TNCO evolution}

The tectonic framework and the tectonothermal events responsible for the building of the North China Craton during Archean-Paleoproterozoic are still debated. Hereafter, we present 
the four main tectonic models that are currently proposed to explain the tectonic evolution of the TNCO and the NCC amalgamation.

3.1. Model 1: collision at 1850 Ma after eastward subduction ([Kröner et al., 2005a], [Kröner et al., 2005b] , [Kröner et al., 2006] , [Li et al., 2010] , [Zhang et al., 2007] , [Zhao et al., 1998] , [Zhao et al., 1999b] , [Zhao et al., 2000a] , [Zhao et al., 2000b] , [Zhao et al., 2001a] , [Zhao et al., 2001b] , [Zhao et al., 2004b] , [Zhao et al., 2005] , [Zhao et al., 2007] and [Zhao et al., 2010] )

The first model was proposed by [Zhao et al., 1998] , [Zhao et al., 1999a] and [Zhao et al., 1999b] and rearranged in subsequent studies ( [Kröner et al., 2005a], [Zhang et al., 2007], [Zhao et al., 2000a] , [Zhao et al., 2000b] , [Zhao et al., 2004a] , [Zhao et al., 2005] , [Zhao et al., 2007] and [Zhao et al., 2010] ). This model argues that the NCC consists of two Archean blocks, the Eastern and Western Blocks that were welded together along the Trans-North China Orogen in response to eastward subduction and subsequent continent-arc-continent collision at $\sim 1850 \mathrm{Ma}$ ( [Kröner et al., 2005a], [Kröner et al., 2005b] , [Kröner et al., 2006] , [Zhang et al., 2007] and [Zhao et al., 2004b] ). Here we present in more detail the model proposed in Zhang et al. (2007) that incorporates elements of [Zhao et al., 1998] , [Zhao et al., 1999a] , [Zhao et al., 1999b] , [Zhao et al., 2000a] and [Zhao et al., 2004b] and Kröner et al. (2005b). Between $2560 \mathrm{Ma}$ and $1880 \mathrm{Ma}$, the Hengshan, Wutaishan and Fuping Massifs were part of a same continental magmatic arc developed after eastward subduction of an ancient ocean beneath the western margin of the Eastern Block. Around 1880-1850 Ma, the closure of the former ocean separating the Eastern and Western Blocks resulted in the continent-arccontinent collisional orogeny and final amalgamation of the North China Craton. The collision was primarily responsible for the development of westward thrusts and isoclinal folds associated with a penetrative foliation accompanying prograde metamorphism. In this model, the deformation responsible for crustal thickening is mainly defined by a top-to-the NW shearing ( [Kröner et al., 2005b] , [Zhang et al., 2007] , [Zhao et al., 2004a] and [Zhao et al., 2004b] ). Ongoing subduction then caused the detachment of the high pressure rocks unit (lower crustal root) along the ductile Zhujiafang shear zone. Finally, during unroofing of the whole thickened crust, and in response to slab detachment, upright folds developed regionally while detachment faults affected the shallow crustal levels.

3.2. Model 2: continent-arc-continent collision at 2500 Ma ( [Kusky, 2011], [Kusky and Li, 2003] , [Kusky and Santosh, 2009] , [Li and Kusky, 2007] , [Li et al., 2000a] , [Li et al., 2000b] , [Polat et al., 2005] and [Polat et al., 2006] ]

In the second model, the Trans-North China Orogen (called the Central Orogenic Belt in this model) represents an Archean continent-arc-continent collision orogen formed around $2.5 \mathrm{Ga}$ after westward subduction of an ancient ocean ( [Kusky and Li, 2003] and [Li and Kusky, 2007] ). An arc terrane represented by the Wutaishan magmatic rocks and an associated forearc ophiolitic belt on its eastern edge collided with the passive margin of the Eastern Block between 2.55 and $2.5 \mathrm{Ga}$ ( [Kusky, 2011] and [Polat et al., 2005] ). From 2.4 to $2.3 \mathrm{Ga}$, the ocean basin between the accreted arc and the Western Block began to close, after westwarddipping or double-sided subduction (Kusky, 2011). After $2.3 \mathrm{Ga}$, the North China Craton is thought to behave as a single block before its northern margin collided with the Columbia supercontinent at $\sim 1.9 \mathrm{Ga}$ ( [Kusky et al., 2007] and [Kusky and Santosh, 2009] ), along an $\mathrm{E}-\mathrm{W}$ trending collisional belt named the Inner-Mongolia-North-Hebei Orogen (IMNHO; Li and Kusky, 2007). From north to south, three zones are distinguished forming the IMNHO: (i) a belt of metasediments deposited in a shallow water environment, (ii) a belt of plutonic rocks, composed of TTG and quartz diorites, which have been metamorphosed under 
greenschist facies conditions and (iii) a belt of supracrustal rocks and metasediments including metavolcanites intruded by gabbros and diorites and metamorphosed in the amphibolite facies (Kusky and Li, 2003). These three zones are interpreted as an accretionary prism, magmatic arc and back arc basin, respectively (Kusky and $\mathrm{Li}, 2003$ ). According to this model, the Paleoproterozoic orogenic event was responsible for a widespread metamorphic overprint in all older events, including the $\sim 1.85 \mathrm{Ga}$ metamorphism recorded in the Hengshan-Wutaishan-Fuping-Luliang Massif in the central NCC.

3.3. Model 3: magmatic arc at 2.5 Ga and collisions at 2.1 Ga and 1850 Ma ([Wang, 2009], [Wang, 2010] , [Wang et al., 2004] and [Wang et al., 2010a] )

This third model, proposed by Wang (2009) and Wang et al. (2010a), is a refinement of Wang et al. (2004) model. The authors suggest that a major ocean, called the Proto-North China Ocean, developed between the Western and Eastern Blocks prior to $2565 \mathrm{Ma}$. Between $\sim 2565$ and $2540 \mathrm{Ma}$, a proto-magmatic arc formed in response to a north-westward intraoceanic subduction. This proto-magmatic arc is presently represented by the $\sim 2565-2540 \mathrm{Ma}$ Wutaishan granitoids. At about $\sim 2540-2525 \mathrm{Ma}$, the proto-arc was rifted, and a back-arc basin formed and evolved toward an intra-oceanic arc-basin system. Within the Wutaishan Massif, this intra-oceanic arc basin system is marked by a MORB-arc-back arc basalt-adakite association greenstone belt as well as synchronous granitoids. During the period $\sim 2525-2475$ Ma, multiple subduction zones accounted for a main subduction-accretion process that resulted in the closure of the Wutai back-arc basin and the development of distinct arc magmas. At 2.3-2.1 Ga, the Lüliang back-arc basin was closed and the Lüliang-HengshanWutai-Fuping arc terranes accreted together. At $\sim 2.1 \mathrm{Ga}$, a collision occurred between the accreted Lüliang-Hengshan-Wutai-Fuping arc terranes and the Western Block (Wang et al., 2010a). The final collision between the Eastern and Western Blocks resulting in amalgamation of the NCC occurred at 1.9-1.8 Ga.

3.4. Model 4: ([Faure et al., 2007] , [Trap et al., 2007] , [Trap et al., 2008] , [Trap et al., 2009a], [Trap et al., 2009b] and [Trap et al., 2011])

This fourth model proposes that an intervening block, named the Fuping Block, lies between the Eastern and Western Blocks ( [Faure et al., 2007] , [Trap et al., 2007] and [Trap et al., 2008] ). These three blocks are separated by the Lüliang and Taihang Oceans. The closure of the Taihang Ocean at ca. 2100 Ma by westward subduction below the Fuping Block accounts for arc magmatism, Lüliang back-arc basin and the 2100 Ma orogeny (Faure et al., 2007). The second collision at 1900-1880 Ma between the Fuping and the Western Blocks is responsible for the main structural, metamorphic and magmatic features of the Trans-North China Orogen. Refinements of this model are proposed in Section 8.

\section{Litho-tectonic zonation of the Trans-North China Orogen}

Here we present the architecture of the TNCO according to the works of Faure et al. (2007) and [Trap et al., 2007] , [Trap et al., 2008] , [Trap et al., 2009a] , [Trap et al., 2009b] and [Trap et al., 2011] . From south-east to north-west, the TNCO consists of several lithological, metamorphic and structural units well identified in the Zanhuang, Fuping, Wutaishan, Lüliangshan, Hengshan, Huai'an-Datong massifs (Fig. 1 and Fig. 2), and also in the northern Xuanhua and Chengde massifs. This section introduces the main lithological features for each unit. The structural, metamorphic and geochronological features will be discussed in the next sections. 


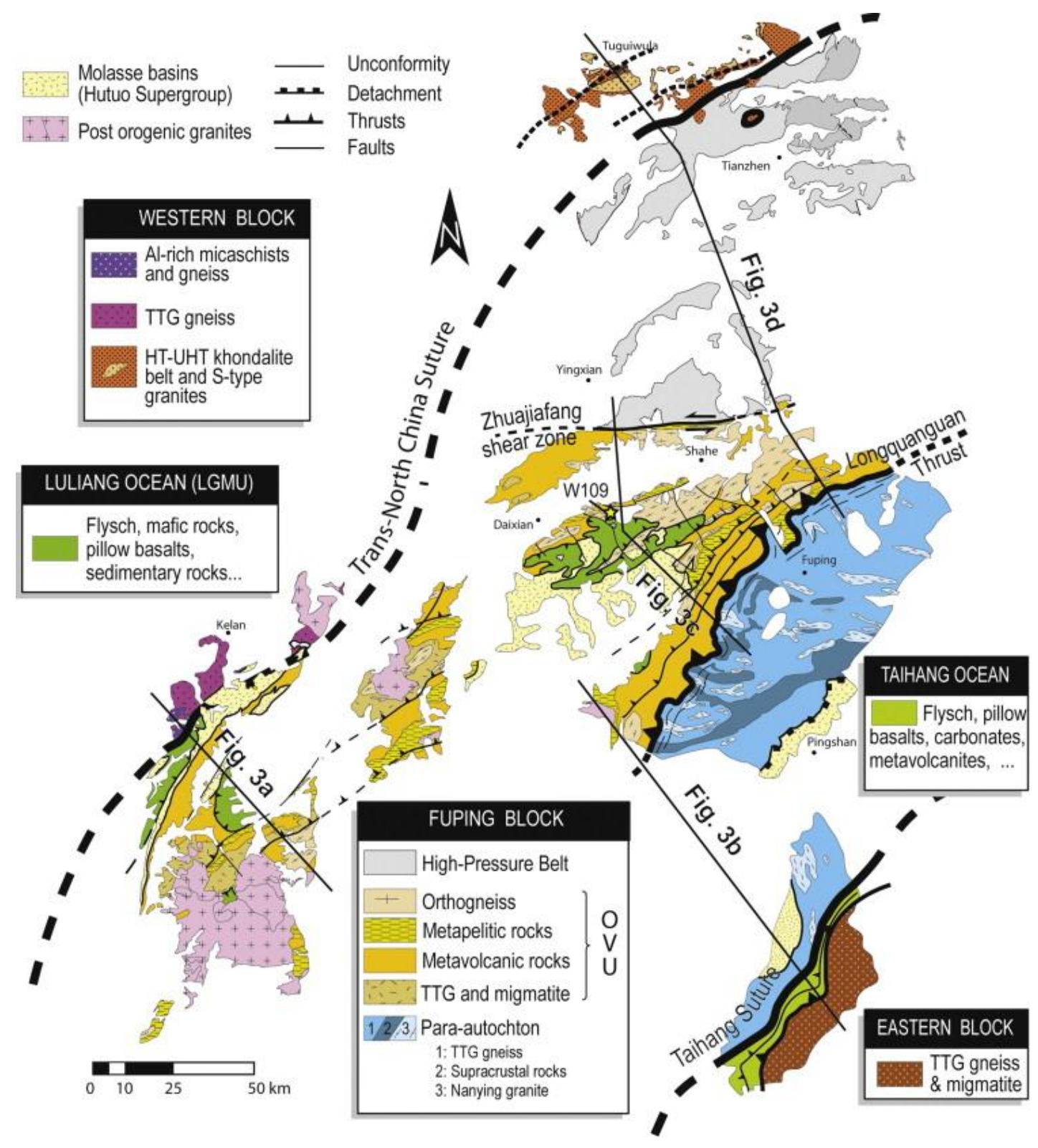

Fig. 2. : Litho-teconic map of the Hengshan-Wutaishan-Fuping-Luliang-Zanhuang-Datong area. The crosssections (a), (b), (c) and (d) located on the map are presented in Fig. 3.

\subsection{The Hutuo Supergroup sedimentary rocks}

The Hutuo Supergroup (HS) constitutes the highest structurally positioned unit within the orogenic pile. In the Lüliangshan, Wutaishan and Fuping Massifs, the HS sedimentary rocks unconformably cover the metamorphic rocks of the Orthogneiss-and-Volcanite Unit (OVU) and Low-Grade-and-Mafic Unit (LGMU) (Fig. 1, Fig. 2 and Fig. 3). The HS sedimentary rocks consist of unmetamorphosed or weakly metamorphosed but locally highly deformed sedimentary series of conglomerate, sandstone, mudstone, and carbonates with subordinate intercalations of volcanic rocks. According to the geological maps of Hebei and Shanxi Provinces ( [HBGMR, 1989] and [SBGMR, 1989] ) and to synthetic works (Yang et al., 1988), we consider the terrigeneous rocks of the Gantaohe Group in the Fuping Massif (HBGMR, 1989) as well as the Yejishan Group (SBGMR, 1989) together within the Hutuo 
Supergroup that is interpreted as a syn-orogenic to late-orogenic formation ( [Faure et al., 2007] and [Trap et al., 2007] ).

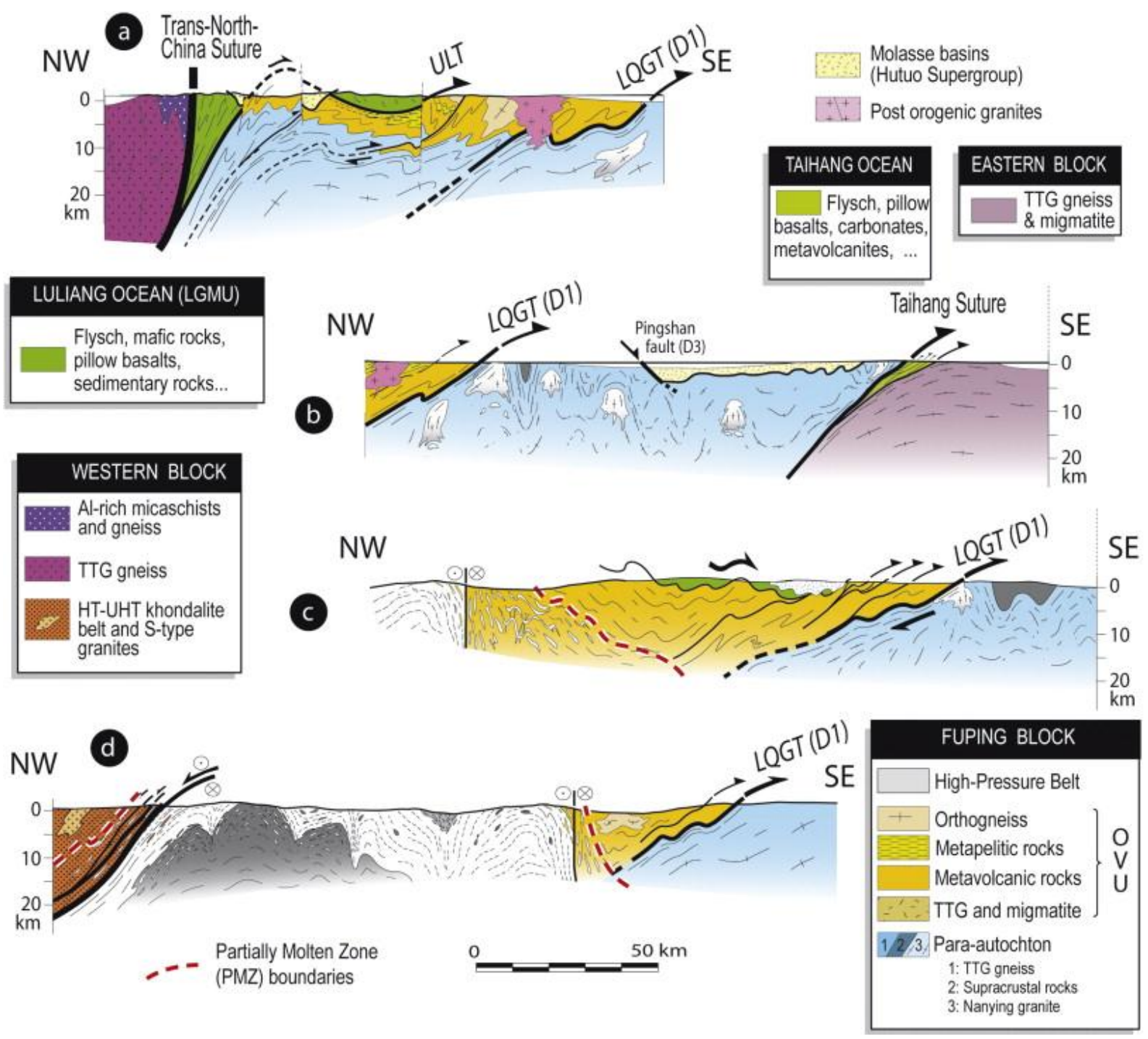

Fig. 3. : Crustal scale cross-sections across the Trans-North China Orogen. See Fig. 2 for cross-section location.

\subsection{The Low-Grade-and-Mafic Unit (LGMU)}

In the LGMU (Fig. 1 and Fig. 2), the most common rock-types are greenschist facies sedimentary and magmatic rocks. Metasedimentary rocks such as pelite, silt, grauwacke, quartzite and volcano-sedimentary rocks such as tuffs or pyroclastites are widespread. Basalt, sometimes with pillow structures, dolerite, gabbro, and variously serpentinized harzburgite and dunite are also widespread. In the western part of the Lüliang Massif, the Upper TNCO metasedimentary rocks consist of centimeter to meter-size sandstone-mudstone alternations derived from a turbiditic series within which some meter-size lenses of mafic and ultramafic rocks are interpreted as olistoliths or mafic intrusions subsequently sheared during the formation of the orogenic wedge ( [Faure et al., 2007] and [Trap et al., 2009b] ). 


\subsection{The Orthogneiss-and-Volcanite Unit (OVU)}

Three distinct typical lithologies are recognized within the OVU (Fig. 2). The first rock-type consists of centimeter to meter-scale alternations of light-colored acidic gneiss and amphibolite, grouped as the metavolcanic rocks (Fig. 2). The acidic gneisses were derived from felsic lavas: rhyolite, dacite, and andesite or volcani-clastic rocks. The protoliths of the amphibolites are mafic magmatic rocks (i.e. lava flows, dykes or sills) or volcanicsedimentary rocks. A second group, called metapelitic rocks (Fig. 2), consists of garnet \pm staurolite \pm kyanite gneisses and micaschists, minor BIF, and marbles that crop out in Lüliangshan, Hengshan and Wutaishan where it is known as the Jingangku Group ( [SBGMR, 1989] and [Tian, 1991] ). The third lithology within the OVU includes the numerous plutons called Chechang-Betai, Ekou, Lanzishan, Sifo, Wangjiahui, Yixingzhai and the grey facies of the Guangminshan massif (Fig. 2).

\subsection{The para-autochthonous domain}

The OVU and LGMU form a stack of nappes thrust toward the SE over a para-autochthonous domain that crops out in the Fuping Massif and the western part of the Zanhuang Massif (Fig. 2 and Fig. 3; [Faure et al., 2007] , [Trap et al., 2007] , [Trap et al., 2008] and [Trap et al., 2009a] ). The para-autochthonous domain is made of domes and basins ( [Trap et al., 2008] and [Trap et al., 2009b] ). The domes are mainly composed of trondhjemitic, tonalitic and granodioritic (TTG) rocks that suffered partial melting with some anatectic granites occurring in dome cores such as the peraluminous granodioritic and monzogranitic Nanying granites ( [HBGMR, 1989] , [Guan et al., 2002] , [Liu et al., 2002] , [Liu et al., 2004] , [Trap et al., 2008] and [Zhao et al., 2002b] ). Basins are made of supracrustal rocks that comprise felsic and pelitic gneiss, pelitic micaschists, calc-silicates, pure and impure marbles and amphibolites (e.g. Liu and Liang, 1997).

\subsection{The Central Zanhuang Domain}

The Central Zanhuang Domain (CZD) forms a $120 \mathrm{~km}$ long and 5-10 km wide stack of supracrustal, gneiss and mafic magmatic rocks. The (CZD) is highly disrupted by several shear zones that led to the interleaving of kilometre-scale orthogneissic and migmatitic thrust slices. From west to east, five litho-tectonic units can be recognized within the CZD: (i) a Quartz Schists Unit, (ii) a Volcanic-sedimentary and Carbonated Flysch Unit, (iii) a Micaschist and Paragneiss Unit, (iv) an Orthogneiss and Migmatite Unit and (v) a Marble Unit. They are globally arranged in the same order, from west to east, as the general dip is consistently westward. Detail on each unit is presented in Trap et al. (2009b). The lithological features suggest that the CZD represents the remnant of an oceanic basin, called the Taihang Ocean ( [Faure et al., 2007] and [Trap et al., 2009b] ).

\subsection{The High-Pressure Belt}

The High-Pressure Belt (HPB; Zhang et al., 2006) consists of high-pressure mafic and felsic granulites that crop out in a NE-SW trending unit of $150 \mathrm{~km}$ wide and $400 \mathrm{~km}$ long belt (Fig. 1 and Fig. 2). High-pressure rocks crop out as $10 \mathrm{~cm}$ to $10 \mathrm{~m}$ scale boudins or flat sheets of retrograded eclogites and high-pressure granulites within migmatites ( [Guo et al., 2002], [Li et al., 1998] , [O'Brien et al., 2005], [Zhai et al., 1992] , [Zhang et al., 2006], [Zhao et al., 2000a] and [Zhao et al., 2001a] ). Trap et al. (2011) documented that the HPB is enclosed in a migmatitic unit called the Partially Molten Zone (PMZ). This zone consists of a core of 
diatexite mantled by metatexite (Trap et al., 2011). The protoliths of the mafic granulites are magmatic rocks of doleritic and gabbroic composition interpreted as mafic dykes intruding a TTG gneissic unit ( [Kröner et al., 2005b] and [O’Brien et al., 2005] ).

\subsection{TTG and Khondalite Series of the Western Block}

The Western Block is composed of a gneissic TTG basement made up of tonalite and granodiorite, covered by metasedimentary rocks, which consist chiefly of graphite-garnetsillimanite gneiss, garnet quartzite, felsic paragneiss, calc-silicate rock and marble (Fig. 2). These rocks belong to the 'Khondalite Series' of the Chinese literature, and are considered to derive from terrigeneous sediments such as mudstone, feldspathic sandstone or graywacke deposited upon the passive continental margin of the Western Block ( [Condie et al., 1992] , [Kusky et al., 2007] , [Wan et al., 2000], [Wan et al., 2006] , [Zhao et al., 2004b] and [Zhao et al., 2005] ). Some khondalitic rocks suffered HT and UHT metamorphism (e.g. [Zhao et al., 2001b] and [Zhai and Santosh, 2011] ). Precisions about P-T conditions and P-T-t path related to HT-UHT and HP metamorphism are given in Section 6.1.

\subsection{TTG of the Eastern Block}

The Eastern Block, in our sense, crops out in the eastern part of the Zanhuang Massif (Fig. 2). It consists mainly of TTG gneiss and migmatites belonging to the high-grade 'Zanhuang Group' ( [HBGMR, 1989] and [Niu et al., 1994] ). Migmatite commonly includes stretched amphibolite boudins, as well as preserved coarse grained orthogneiss and garnet bearing tonalitic gneiss. These TTG rocks experienced an amphibolite to granulite facies metamorphism, with evidence of partial melting (Trap et al., 2009b).

\section{Structural features}

\subsection{Main tectonic boundaries}

\subsubsection{The suture zones}

The knowledge of the precise location of the sutures zones is of critical importance for the understanding of any orogenic system. On the contrary to previous studies that proposed tectonic models with 'cryptic' sutures zones without any detail, Faure et al. (2007) and [Trap et al., 2007] , [Trap et al., 2008] , [Trap et al., 2009a] and [Trap et al., 2009b] first documented two main lithospheric boundaries: the Trans-North China Suture and the Taihangshan Suture (termed Taihang Suture in the present paper).

The Trans-North China Suture (TNCS) crops out in the western part of the Lüliang Massif (Fig. 1, Fig. 2 and Fig. 3). It is represented by greenschist facies meta-sediments, mafic and ultramafic rocks. Since we interpreted these rocks as the remnant of the Lüliang Ocean, we grouped them in the LGMU (see Section 4.2). Its southern extension remains unknown. However, this suture extends northeastward along the eastern edge of the Khondalite Unit. In this scheme, the TNCS separates the Khondalite Unit (i.e. the Western Block) from the HPB (i.e. the Fuping Block, Trap et al., 2011). The boundary is represented by the ChengdeDatong shear zone (Trap et al., 2011). Thus the trend of the suture zone does not continue northward (Zhao et al., 2004b), but takes an ENE-SSW direction in the north of Datong. However, from Datong to Chengde even if some gabbroic and anorthositic rocks crop out, the 
LGMU representative of the TNCS does not appear anymore since the Chengde-Datong shear zone activity erased the primary geometry (see Trap et al., 2011 for details).

The Taihang Suture is a major mylonitic domain along which amphibolitic rocks, pillow-lavas and turbiditic rocks belonging to the Central Zanhuang Domain occur (Trap et al., 2009a). This tectonic boundary separates the eastern edge of the Fuping Block (represented by the para-autochthonous domain) from the Eastern Block (Fig. 3; [Faure et al., 2007] and [Trap et al., 2009a] ). The field results are confirmed by recent geophysical data that suggest this discontinuity is lithospheric-scale and that its geometry is consistent with a westward dipping subduction zone (Zheng et al., 2009).

\subsubsection{Others main tectonic contacts}

The Longquanguan Thrust (LQGT), previously called Longquanguan Shear Zone, consists of a $200 \mathrm{~km}$ long and $\sim 2 \mathrm{~km}$ thick ductile shear zone that involves both rocks from the Fuping Massif and the OVU (Fig. 2 and Fig. 3). In agreement with Li et al. (2004), we argue that the LQG Shear Zone consists of a major low angle thrust fault and therefore we prefer to use the term "Longquanguan Thrust" (LQGT). Indeed, several studies ( [Hao et al., 1995] , [Pei et al., 2001] , [Sun et al., 2004] and [Trap et al., 2007] ) documented this tectonic boundary as a north-westward gently dipping mylonitic foliation with top-to-the SE kinematic criteria along the NW-SE striking stretching lineation (L1).

The Upper Wutai Thrust and the Upper Lüliang Thrust are two ductile faults that constitute the tectonic contact between the LGMU and the underlying OVU (Fig. 3). The Upper Lüliang Thrust (ULT, Fig. 3) is well exposed along the Suiyu Valley, northeast of Mafang, where it appears as a flat lying (S1 dip $<20^{\circ}$ ), several meters thick shear zone made of mylonitized or even ultramylonitized acidic augen gneiss derived from the OVU (Trap et al., 2009b). The Upper Wutai Thrust consists of several discrete centimeter-scale mylonitic and ultramylonitic zones that as a whole form a 10-m thick ductile tectonic boundary between the LGMU and OVU (Fig. 2 and Fig. 3; Trap et al., 2007). Along both shear zones, top-to-the SE shearing is clearly demonstrated ( [Faure et al., 2007] , [Trap et al., 2007] , [Trap et al., 2008] and [Trap et al., 2009b] ). In Fig. 3 cross-sections, the ULT and UWT are drawn as a folded, but initially flat lying, shear zones along which the LGMU nappe emplaced from the NW to the SE, upon the OVU. The LGMU nappe is rooted along the Trans-North China Suture (Fig. 3).

The Zhujiafang strike-slip shear zone (ZSZ) separates the Northern Hengshan Massif from the southern Hengshan Massif (Fig. 2). Along the ZSZ, the moderately dipping S2 or S1-2 is continuously deflected into an E-W trending steeply dipping mylonitic fabric. The mylonitic to ultramylonitic foliation holds a horizontal to shallowly plunging stretching lineation along which a sinistral kinematics is observed ( [Trap et al., 2007] and [Wang, 2010] ). Along the strike-slip shear zone, but out of the high-strain domain, a down-dip to highly plunging lineation, with the southern side moving downward, accounts for an early vertical movement (Trap et al., 2007).

\subsection{Finite strain, kinematics and polyphase deformation}

The works of Faure et al. (2007) and [Trap et al., 2007] , [Trap et al., 2008] , [Trap et al., 2009a] , [Trap et al., 2009b] and [Trap et al., 2011] yield to a complete structural analysis with the recognition of four main structural stages (labeled hereafter D1-D4), responsible for the structuration of the TNCO. Details of each deformation stage are given below. 


\subsubsection{D1 deformation: thickening throughout nappe stacking}

The D1 finite strain is defined by a penetrative $\mathrm{S} 1$ foliation that predominates within most of metamorphic rocks except in the partially molten rocks of the HPB ( [Trap et al., 2007] and [Trap et al., 2011] ). The S1 foliation holds a NW-SE trending mineral and stretching L1 lineation along which top-to-the SE kinematics is observed ( [Dirks et al., 1997] , [Trap et al., 2007] and [Trap et al., 2009b] ). The L1 and S1 strain patterns are particularly well developed along the two subhorizontal tectonic contacts of the Upper Wutai Thrust (UWT) and Longquanguan Thrust (LQGT) at the base of the LGMU and OVU nappes, respectively, where gneissic foliation evolves toward mylonitic and ultramylonitic fabrics (Trap et al., 2007). Isoclinal F1 folds with axes parallel to L1 are also developed within the S1 foliation.

\subsubsection{D2 deformation: ongoing folding}

The S1-L1-F1 fabrics and the bedding (S0) observed in the Hutuo Supergroup sedimentary rocks are deformed by a D2 deformation. F2 folds represent the most pervasive structural elements with a steeply to moderately northwestward dipping axial plane $\left(50-80^{\circ}\right)$ striking around N20E-N60E. These open to tight F2 folds are observed over a range of scale from several meters to decameters. Kilometric-scale F2 folds are sometimes observed in the landscape or inferred from S1 attitude (Trap et al., 2009b). The F2 folds are mainly overturned to the SE. However, F2 upright folds and northward verging overturned F2 folds predominate in northern Wutaishan and Southern Hengshan, respectively. This change in fold vergence forms a fan-type geometry (Fig. 3; [Li et al., 2010], [Trap et al., 2007] and [Zhang et al., 2007] ). The F2 folding is coeval with the development of a S2 cleavage. This axial planar cleavage developed in the Hutuo sediments as well as in the metatexite from the lower section of the OVU ( [Trap et al., 2009b] and [Trap et al., 2011] ). Indeed, in the HighPressure Belt, the D2 deformation is synchronous with partial-melting (Trap et al., 2011). In this area, a SW-NE to E-W trending coaxial flow and doming that developed in the migmatitic core of the HPB is interpreted to result from interplay between diapirism and SENW to N-S shortening, during the eastward extrusion of the deep crust (Trap et al., 2011). Extrusion is accompanied by top-to-the W and top-to-the SW shearing observed in the western edge of the HPB. The flow direction turns from NNE-SSW in the southwestern part of the HPB to E-W in the middle and eastern parts, i.e. it parallels the Trans-North-China Suture.

\subsubsection{D3 deformation: normal shearing}

In the southeastern edge of the Fuping Massif, the Late Paleoproterozoic Gantaohe Group is separated from the underlying Fuping migmatite and Supracrustal rocks by the Pingshan lowangle 10-m-thick ductile normal fault (Trap et al., 2008). The foliation (denoted here as S3) strikes consistently NE-SW and dips at $30^{\circ}$ toward the southeast. A consistent N130E trending mineral lineation (L3) is well defined along which a consistent top-to-the SE normal sense of shear is observed (Trap et al., 2008). A main detachment ductile fault separating the HPB and the Khondalite Unit is considered to have accommodated extension after crustal thickening ( [Zhang et al., 1994] , [Wu and Zhong, 1998] and [Guo et al., 2002] ). According to Trap et al. (2011) this detachment zone at the conjunction of the Khondalite Unit and HPB constitutes the western part of the Datong-Chengde Shear Zone (DCSZ) that appears as a kilometre-scale ductile normal shear zone with a sinistral strike-slip component. The activity of the DCSZ may account for the late stage of the exhumation and eastward tectonic escape of the HPB (Trap et al., 2011). 


\subsubsection{D4 deformation: late-collisional strike-slip shearing}

The D4 event is restricted to the Hengshan Massif and the northern part of the Wutaishan Massif. It is characterized by the development of strike slip shear zones among which the most significant is the kilometre-scale Zhujiafang Shear Zone (Fig. 2). Within the ZSZ, the subvertical mylonitic to ultramylonitic foliation holds an E-W trending mineral lineation associated with a sinistral sense of shear ( [Trap et al., 2007] , [Wang, 2009] and [Wang, 2010] ). Some other studies argue for a dextral sense of shear along the ZSZ (Zhang et al., 2007).

\section{Metamorphic evolution}

\subsection{Contrasted P-T paths within the TNCO}

The TNCO is defined by discrete tectono-metamorphic units with distinct $\mathrm{P}-\mathrm{T}$ evolutions. Most of the published $\mathrm{P}-\mathrm{T}$ paths have been obtained for rocks sampled within the Khondalite Unit, the High-Pressure Belt, and the OVU (Fig. 4). In this section we summarize the main P$\mathrm{T}$ paths recorded by these metamorphic rocks and discuss their significance.

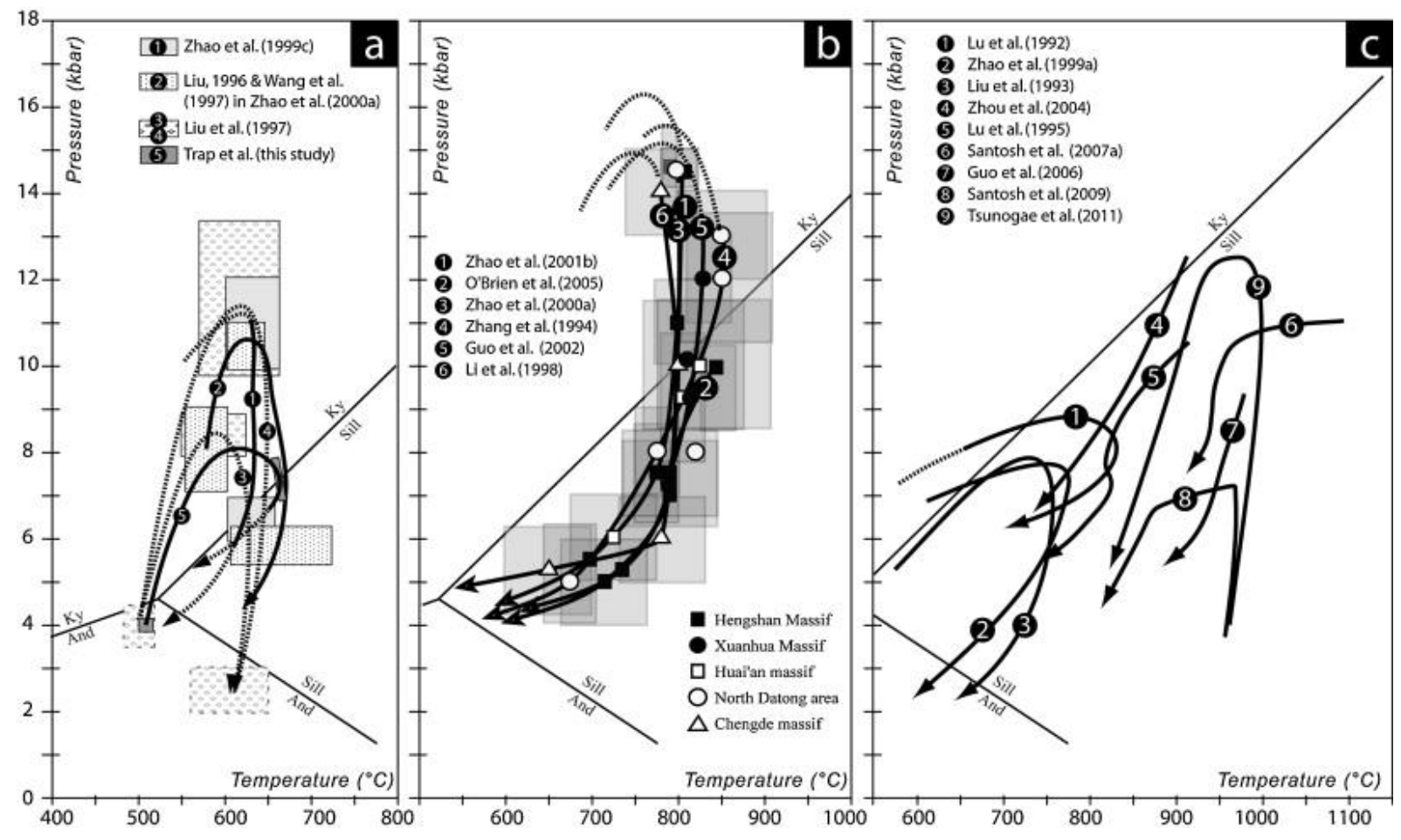

Fig. 4. : Summary of P-T metamorphic paths recorded for rocks within the OVU (a), HPB (b) and Khondalite Series (c).

\subsubsection{P-T evolution of the OVU amphibolite facies rocks}

So far, the only quantitative $\mathrm{P}-\mathrm{T}$ path, using multi-equilibrium approach computed for Wutaishan OVU metamorphic rocks has been proposed by Zhao et al. (1999c). These authors constructed a clockwise P-T path for the garnet bearing amphibolites that crop out in the southern and northern edges of the Wutaishan Massif. The P-T evolution shows 4 stages 
(M1-M4): initial burial (M1 and M2), isothermal decompression (M3), cooling and retrogression (M4). However, only the peak M2 P-T conditions and M3 were represented by sufficient metamorphic assemblages helping the authors to calculate the $\mathrm{P}-\mathrm{T}$ conditions using internally consistent forward modelling with Tweequ software ( [Berman, 1988] and [Berman, 1991] ). The P-T path is obtained on several rocks that record either M2 or M3 but not both of them. Thus, the P-T path is a composite one. In addition, [Zhao et al., 1999c] and [Zhao et al., 2000a] proposed a quite similar P-T path based on thermobarometric results of Liu (1996) and Wang et al. (1997; Fig. 4a). The two P-T paths show the same evolution with a clockwise retrogressive, nearly isothermal, decompression trajectory but the prograde evolution is not precisely documented.

\subsubsection{P-T evolution of the HP rocks within the HPB}

The reconstructed $\mathrm{P}-\mathrm{T}$ paths obtained for the high-pressure mafic granulites of the HPB are characterized by a clockwise evolution with a near-isothermal decompression followed by a final cooling (Fig. 4b). Peak assemblages (M1) are defined by a granulite facies garnet + clinopyroxene \pm quartz association, and sometimes by an eclogite facies mineral assemblage of garnet + quartz + omphacite pseudomorphs ( [Zhang et al., 2006] and [Zhao et al., 2001a] ). The $\mathrm{P}-\mathrm{T}$ path is then defined by medium-pressure granulite facies garnet + plagioclase + clinopyroxene + orthopyroxene \pm quartz assemblage (M2) and a low-pressure granulite facies orthopyroxene \pm clinopyroxene + plagioclase \pm quartz assemblage (M3). The end of the $\mathrm{P}-\mathrm{T}$ path is defined by an amphibolite facies hornblende + plagioclase assemblage (M4). M1 took place at $800-850^{\circ} \mathrm{C} / 14-16 \mathrm{kbar}, \mathrm{M} 2$ and $\mathrm{M} 3$ occurred for T/P conditions of $800-825^{\circ} \mathrm{C} / 10$ kbar and $800{ }^{\circ} \mathrm{C} / 7-8 \mathrm{kbar}$, respectively. Thermo-barometric conditions of $650{ }^{\circ} \mathrm{C} / 5 \mathrm{kbar}$ were estimated for M4 ( [Guo et al., 2002] , [0135] , [Liu et al., 1993] , [O’Brien et al., 2005], [Zhai et al., 1992] , [Zhai et al., 1995] , [Zhang et al., 1994] , [Zhang et al., 2006], [Zhao et al., 2000a] and [Zhao et al., 2001a] ).

\subsubsection{P-T evolution of the HT-UHT granulites in the Khondalite Unit}

High-temperature (HT) granulites occur extensively within the Khondalite Unit with metamorphic P-T conditions in the range of $760-850{ }^{\circ} \mathrm{C}$ and $0.5-0.8 \mathrm{GPa}$ (e.g. [Zhai et al., 2010] and [Zhao et al., 2001b] ). It consists of metapelites with a representative assemblage of garnet + sillimanite + cordierite + spinel + K-feldspar + biotite + quartz + rutile . These highgrade rocks are interpreted as evidence for collision between the Yinshan Block and the Ordos Block ( [Kusky et al., 2007], [Santosh et al., 2007a], [Santosh et al., 2007b] and [Zhao et al., 2005] ). The HT granulites record a clockwise P-T path with a near isothermal decompression (Fig. 4c; [Liu et al., 1993] , [Lu et al., 1992] and [Zhao et al., 1999a] ). For some granulites, only the near isothermal decompression is recorded preventing to decipher between clockwise or anticlockwise P-T path (Lu et al., 1995). More recently, P-T estimates performed on diagnostic minerals, such as saphirine + quartz, Al-rich orthopyroxene + sillimanite + quartz assemblages or using Zr-in-rutile thermometry attest that some granulitic rocks within the Khondalite Unit suffered UHT metamorphism with temperature in excess of $900{ }^{\circ} \mathrm{C}$ and even higher than $1000{ }^{\circ} \mathrm{C}$ and pressure at ca. $1.0 \mathrm{GPa}$ ( [0770] , [Jiao et al., 2011] , [Jiao and Guo, 2010] , [Liu et al., 2010], [Santosh et al., 2007a] and [Santosh et al., 2009] ). Some of the UHT rocks are characterized by an anti-clockwise P-T path defined by an isobaric cooling segment followed by isothermal decompression (Fig. 4c; [Liu et al., 2010] , [Santosh et al., 2007a] , [Santosh et al., 2009] and [Tsunogae et al., 2011] ). 


\subsection{Significance of the 1.85-1.9 Ga metamorphism}

One of the main disputed points about the TNCO tectonic evolution is the significance of the 1.85-1.9 Ga metamorphic event. Previous petrological and geochronological studies within the TNCO concluded that rocks underwent a regional metamorphism characterized by clockwise $\mathrm{P}-\mathrm{T}$ paths, involving isothermal decompression and subsequent cooling, reflecting continental collision at $\sim 1850 \mathrm{Ma}$ ( [Kröner et al., 2006], [Zhao et al., 2000a] and [Zhao et al., 2005] ). Alternatively, Kusky and Li (2003) suggested that the $\sim 1.85 \mathrm{Ga}$ metamorphic record in the TNCO resulted from thermal gradient changes due to collision along the IMNHO. According to Kusky et al. (2007), the 1.85-1.9 Ga metamorphic event in the North China Craton is not associated with the North-South striking TNCO but resulted from a strong overprint by the IMNHO-related collision along the northern border of the NCC with the Columbia supercontinent.

\subsection{New insights about prograde metamorphic evolution during D1}

In this section we present a reliable quantitative $\mathrm{P}-\mathrm{T}$ path investigation through the combination of pseudosections calculated in the MnNCKFMASH system and thermobarometry performed on one well preserved Ky-bearing gneiss. The studied rock (sample W109), previously investigated for geochronological data (Trap et al., 2007) was sampled in the northern border of the Wutaishan Massif in the middle part of the TNCO (Fig. 8). Hereafter we present new petrological data using forward modelling obtained on a Kybearing gneiss that bring new insight about the significance of the $1.85-1.9 \mathrm{Ga}$ metamorphism.

\subsubsection{Sample petrography and mineral chemistry}

Sample W109 was collected from the northern edge of the Wutaishan Massif within the 'Orthogneiss and Volcanite Unit' at location (N39 $06.679^{\prime} / \mathrm{E} 113^{\circ} 14.334^{\prime}$; Fig. 8). It consists of a medium grained matrix of quartz, biotite and muscovite within which garnet and staurolite occur as porphyroblasts. The sample shows a pervasive deformation with the planar and linear fabric that characterizes the D1 deformation. In particular, the top-to-the SE shearing along L1 is indicated by asymmetric pressure shadows around garnet, sigmoidal shaped staurolite and biotite aggregates as well as asymmetric kyanite grains (Fig. 5). 


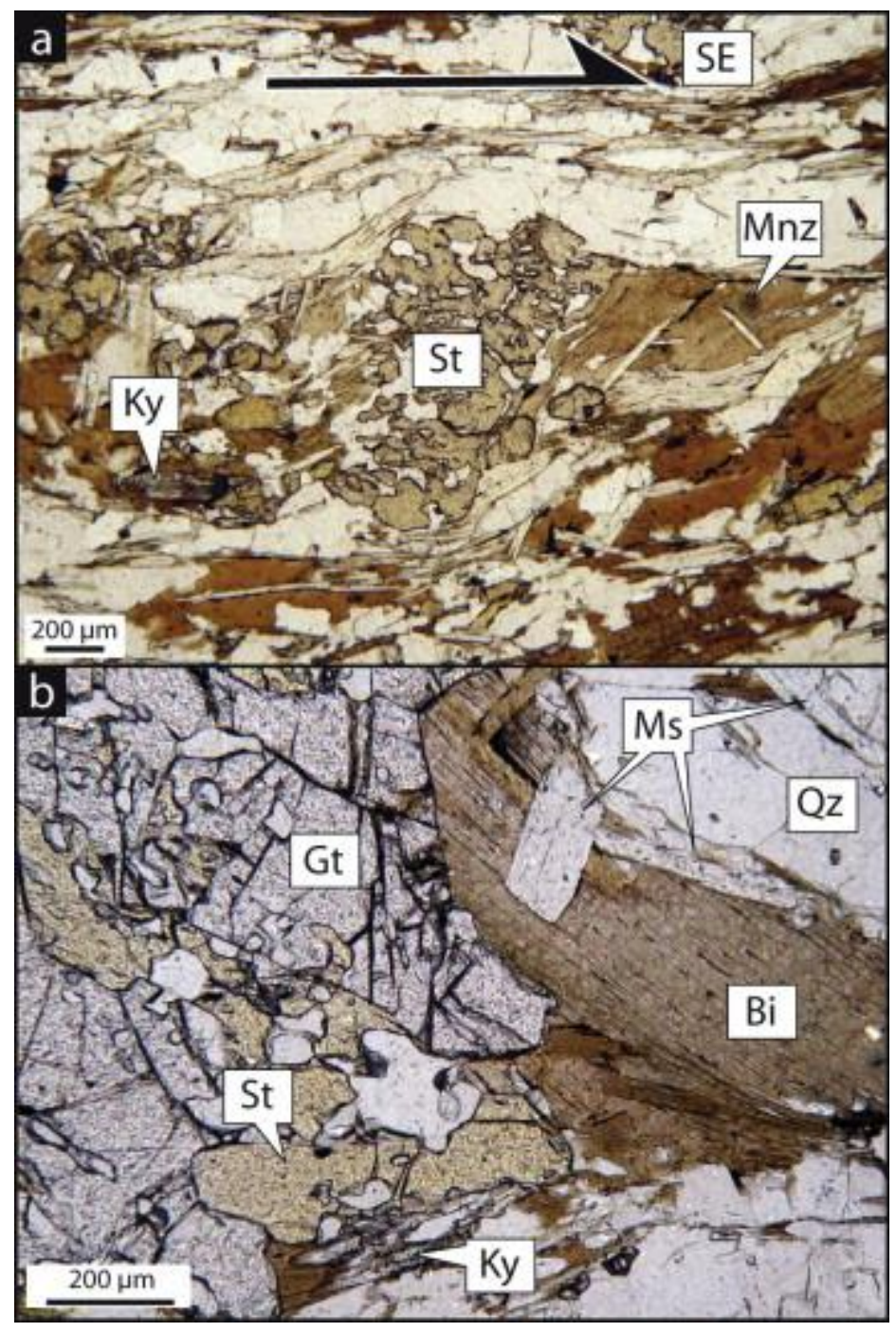

Fig. 5. : Photomicrographs showing the paragenesis and texture of the W109 garnet-staurolite (st)-kyanite (ky)bearing gneiss (sample W109). (a) Asymmetrical staurolite (st) porphyroblast system showing the D1 top-to-the SE kinematics. (b) Equilibrium texture between garnet (gt)-rim, staurolite (st), biotite (bi), muscovite (ms), kyanite (ky) and quartz (qz).

Compositional zoning of $\mathrm{Fe}, \mathrm{Mg}, \mathrm{Ca}$ and $\mathrm{Mn}$ within garnet was investigated qualitatively and quantitatively using X-ray maps and single spots analyses traverses, respectively (Fig. 6 and Appendix A). Strong shape anisotropy of the zoning from core to rim is defined in relation with orientation of the finite strain axes. Along the maximum elongation $X$ axis, zoning is broadly continuous from core to rim. Cores are enriched in $\mathrm{Ca}\left(X_{\mathrm{Gro}}=0.15-0.17\right)$ and $\mathrm{Mn}\left(X_{\mathrm{Spe}}=0.08-0.09\right)$ and depleted in $\mathrm{Mg}\left(X_{\mathrm{Py}}\right.$ $=0.02)$ and $\mathrm{Fe}\left(X_{\mathrm{Alm}}=0.70-0.74\right)$ relative to the $\operatorname{rim}\left(X_{\mathrm{Gro}}=0.01-0.02 ; X_{\mathrm{Spe}}=0.00-0.01 ; X_{\mathrm{Py}}=0.13-\right.$ $0.16 ; X_{\mathrm{Alm}}=0.82-0.85$; see Appendix A). Along the minimum elongation $Z$ axis, the $\mathrm{Fe}, \mathrm{Mg}, \mathrm{Ca}$ and Mn contents exhibit a clear discontinuous zoning from core to rim (Fig. 6). The observed zonation pattern suggests preferential dissolution of garnet perpendicular to $X$ axis, which is linked to the growth of staurolite during prograde metamorphism ( [Spear and Pyle, 2002] , [Khon and Malloy, 2004] and [Fitzsimons et al., 2005] ) here under non-hydrostatic stress tensor. 


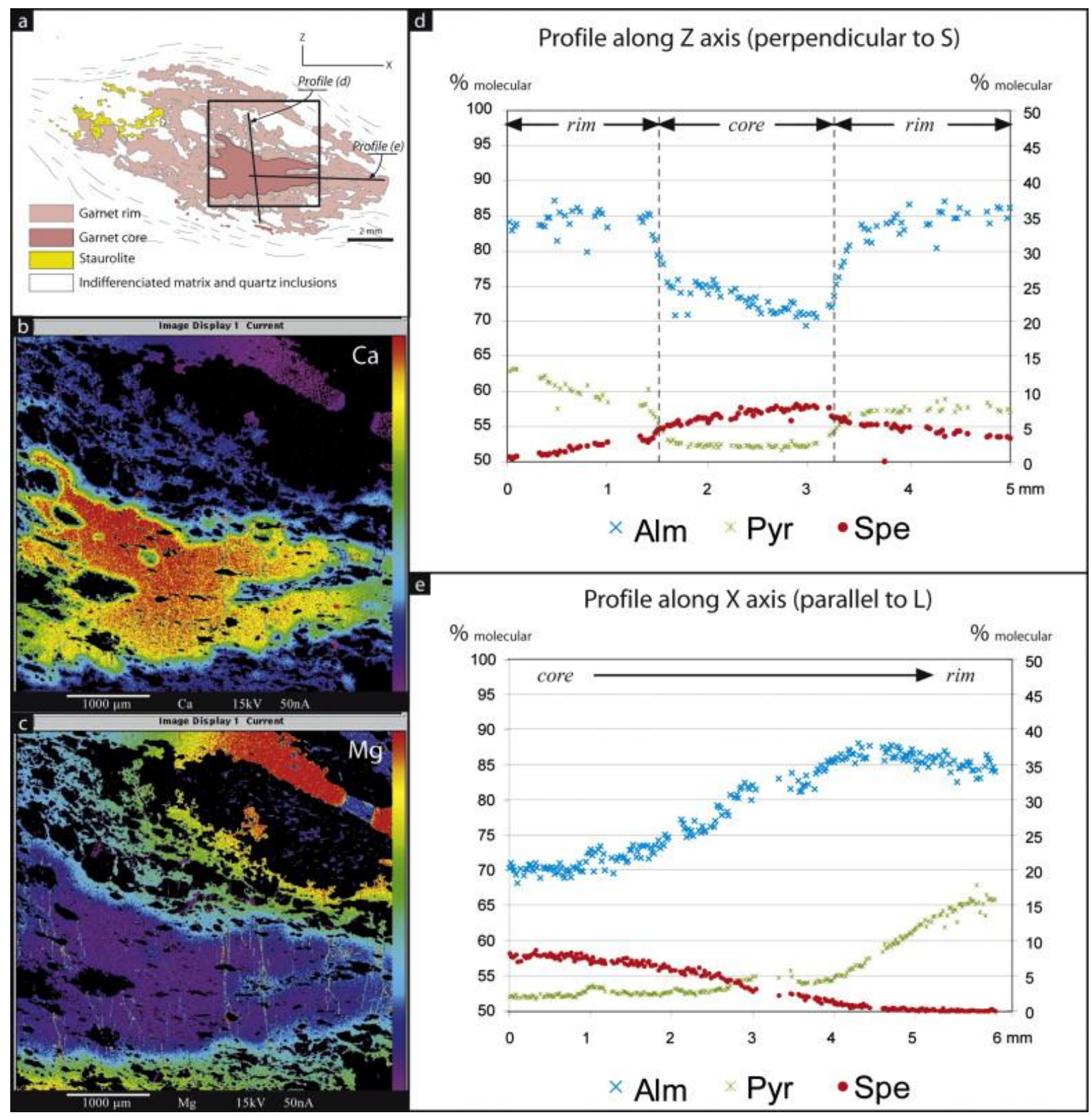

Fig. 6. : Compositional zoning within a garnet porphyroblast (a) with X-ray element maps for $\mathrm{Ca}$ (b) and $\mathrm{Mg}$ (c) and profiles along $Z$ axis (d) and $X$ axis (e). The continuous zoning of garnet as observed along the $X$ axis (profile (e)) show typical features of garnet growth under amphibolite facies conditions and accounts for the fractionation of Mn during prograde metamorphism ( [Hollister, 1966] and [Spear et al., 1990] ). In the direction perpendicular to $X$ axis, the zoning is discontinuous. Moreover, on the Ca-map (b) one can appreciated that the upper rim is directly on contact with the innermost core, the richest in spessartine and calcium $\left(X_{\text {Spe }}=0.00-0.01\right.$; $X_{\text {Gro }}=0.01-0.02$ ) whereas the lower rim do not show the same compositional change suggesting garnet resorption along rims parallel to $X$.

Staurolite grains are chemically homogeneous, whatever their textural position (Appendix B). $\mathrm{Mg}$ content is constant, with $X_{\mathrm{Fe}}=0.82$, and $\mathrm{Zn}$ content is insignificant $X_{\mathrm{Zn}}=0.00-0.01$. Biotite grains, within matrix and within pressure shadows around garnet, are chemically homogenous with $X_{\mathrm{Fe}}=0.49-0.51$ (Appendix C). White mica is mainly a binary solid solution of muscovite (74 mol\%) and paragonite $(14 \mathrm{~mol} \%)$ and is homogenous in composition (Appendix D). 


\subsection{2. $\mathrm{P}-\mathrm{T}$ conditions of garnet nucleation and peak metamorphism}

The $\mathrm{P}-\mathrm{T}$ conditions of peak metamorphism was first investigated using the "average $\mathrm{P}-\mathrm{T}$ " mode of THERMOCALC 3.25 (Powell and Holland, 1988) that yields peak P-T conditions of $9.0 \pm 2.5 \mathrm{kbar}$ and $642 \pm 29^{\circ} \mathrm{C}$ (Table 1). As a complement, a second approach using pseudosections was carried out using THERMOCALC 3.25 ( [Powell and Holland, 1988] and [Powell and Holland, 1994] ), the thermodynamic data from Holland and Powell (1998), the MnCNKFMASH model chemical system, and the activity-composition relationships from Tinkham et al. (2001). The effective chemical composition of the equilibrated system at this highest metamorphic temperature was estimated by removing from the whole system those parts of zoned garnet porphyroblasts which were out of equilibrium at that time. Hence, a second bulk-rock composition (W109-2; Appendix E) was estimated after subtraction of the core of $18 \%$ core of garnet estimated by point-counting. The stability domain of the qz $+\mathrm{bi}+$ $\mathrm{mu}+\mathrm{st}+\mathrm{g}+\mathrm{ky}$ assemblage at equilibrium together with isopleths calculation yields $\mathrm{P}-\mathrm{T}$ conditions ranging between 6.8 and $7.8 \mathrm{kbar}$ and $650-660^{\circ} \mathrm{C}$ (Fig. 7).

\begin{tabular}{|l|l|}
\hline Independent set of reactions & Results \\
\hline (1) $\mathrm{mu}+2 \mathrm{phl}+6 \mathrm{q}=\mathrm{py}+3 \mathrm{cel}$ & $P=9.0 \pm 1.5 \mathrm{kbar}$ \\
\hline (2) $2 \mathrm{east}+6 \mathrm{q}=\mathrm{py}+\mathrm{mu}+\mathrm{cel}$ & $T=642 \pm 29{ }^{\circ} \mathrm{C}$ \\
\hline (3) $3 \mathrm{east}+7 \mathrm{q}+2 \mathrm{ky}=2 \mathrm{py}+3 \mathrm{mu}$ & cor $=-0.186$ \\
\hline (4) $23 \mathrm{phl}+2 \mathrm{mst}+62 \mathrm{q}=18 \mathrm{py}+23 \mathrm{cel}+4 \mathrm{H} 2 \mathrm{O}$ & sigfit $=1.36(1.49)$ \\
\hline (5) $\mathrm{ann}+\mathrm{q}+2 \mathrm{ky}=\mathrm{alm}+\mathrm{mu}$ & \\
\hline (6) $\mathrm{alm}+6 \mathrm{east}+18 \mathrm{q}=4 \mathrm{py}+3 \mathrm{mu}+3 \mathrm{fcel}$ & \\
\hline (7) $69 \mathrm{east}+6 \mathrm{fst}+186 \mathrm{q}=46 \mathrm{py}+8 \mathrm{alm}+69 \mathrm{mu}+12 \mathrm{H} 2 \mathrm{O}$ & \\
\hline
\end{tabular}

Table 1. Results for peak P-T estimation using the multi-equilibrium approach (Fig. 7). Multi-equilibrium calculations were realized with the mode "Average-P-T" of THERMOCALC 3.26 ( [Powell and Holland, 1988] and [Powell and Holland, 1994] ). The analyses used in the computation are given in Appendices A, B, C and D. Average pressures, temperatures and corresponding uncertainties ( \pm 1 sigma) are derived from the independent set of equilibria. The "cor" correlation coefficient between pressure and temperature is -0.186 and therefore the uncertainty ellipse is moderately flattened with a main axis having a negative slope (Powell and Holland, 1994). The uncertainty ellipse was calculated at the 2 "sigma" level. Since the diagnostic parameter called "sigfit = 1.36 " is lower than the cutoff value (1.49) the P-T results are consistent with the input data within their uncertainties (Powell and Holland, 1994). 

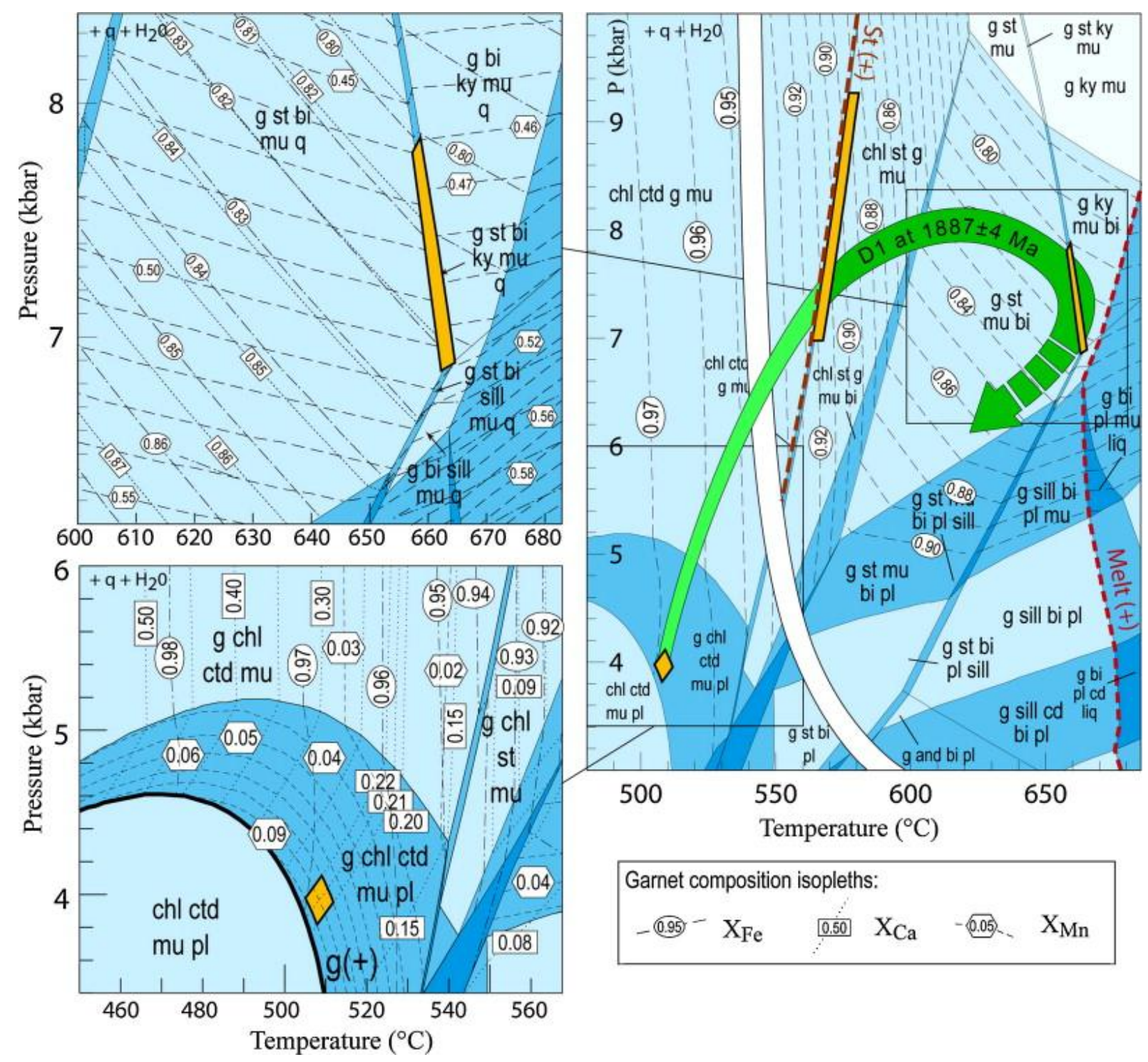

Fig. 7. : Pseudosection calculated in the model MnNCKFASH for system W109-1 (left part) and W109-2 (right part). Zooms shown on top of the figure highlight the relationships between the different compositional isopleths. The $\mathrm{P}-\mathrm{T}-\mathrm{t}-\mathrm{D}$ path corresponds to prograde metamorphism during D1. Garnet nucleation (yellow diamond) is constrained at $4 \mathrm{kbar}$ and $510^{\circ} \mathrm{C}$ and the peak metamorphism (maximum temperature) condition range is $6.8-7.8 \mathrm{kbar}$ and $650-660^{\circ} \mathrm{C}$. The mineral abbreviations used are: mu, muscovite; q, quartz; chl, chlorite; ctd, chloritoid; g, garnet; st, staurolite; bi, biotite; ky, kyanite; sill, sillimanite; and, andalusite; pyrope; Py, Spessartine; Sps, grossulaire, Gro; Almandin; Alm, the isopleth notation used is: $x(\mathrm{~g}, \mathrm{st}, \mathrm{bi})=\mathrm{Fe} /(\mathrm{Fe}+\mathrm{Mg})$, $y(\mathrm{~g})=\mathrm{Ca} /(\mathrm{Ca}+\mathrm{Fe}+\mathrm{Mg}), z(\mathrm{~g})=\mathrm{Mn} /(\mathrm{Mn}+\mathrm{Ca}+\mathrm{Fe}+\mathrm{Mg})$. (For interpretation of the references to color in this figure legend, the reader is referred to the web version of the article.)

Composition isopleths were calculated from bulk-rock composition W109-1 in order to apprehend the chemical evolution of garnet core after garnet nucleation. Isopleths for $\mathrm{Fe}, \mathrm{Ca}$ and $\mathrm{Mn}$ are drawn on the $\mathrm{P}-\mathrm{T}$ pseudosection (Fig. 7). $X_{\mathrm{Fe}}$ and $X_{\mathrm{Ca}}$ isopleths are vertical, showing a decrease in $\mathrm{Fe}$ and $\mathrm{Ca}$ content when increasing temperature at least for chlorite bearing assemblages. Within the $\mathrm{g}+\mathrm{chl}+\mathrm{ctd}+\mathrm{pl}+\mathrm{mu}+\mathrm{q}+\mathrm{H}_{2} \mathrm{O}$ stability field where $X_{\mathrm{Mn}}$ isopleths are nearly parallel to the garnet-in (g+) boundary, and cut the $X_{\mathrm{Fe}}$ and $X_{\mathrm{Ca}}$ isopleths at high angles. Considering the innermost garnet core with a composition of $X_{\mathrm{Fe}}=0.97, X_{\mathrm{Ca}}=$ 0.21 and $X_{\mathrm{Mn}}=0.09, \mathrm{P}-\mathrm{T}$ conditions of $4 \pm 0.2 \mathrm{kbar}$ and $510 \pm 10^{\circ} \mathrm{C}$ is modelled for garnet nucleation. 


\subsubsection{Pressure-Temperature-time-Deformation (P-T-t-D) path}

The attitude of the prograde path that links the $\mathrm{P}-\mathrm{T}$ conditions of garnet nucleation and peak $\mathrm{P}-\mathrm{T}$ conditions is constrained by the garnet chemical composition provided by isopleths along the staurolite-in reaction line (Fig. 7). The Fe content within the inner part of garnet rims $\left(X_{\mathrm{Fe}}\right.$ $=0.90 \pm 0.02$, Appendix A) corresponds to a pressure range of 7-9.2 kbar. The proposed $\mathrm{P}-\mathrm{T}$ path shows a clockwise evolution with a pressure peak around $8 \mathrm{kbar}-620{ }^{\circ} \mathrm{C}$ (Fig. 7). Trap et al. (2007) performed in situ U-Th/Pb EPMA dating on monazite from the sample W109. Monazite grains range in size from $10 \mu \mathrm{m}$ to $80 \mu \mathrm{m}$ and do not show any chemical zonation. This allows us to calculate a single age at $1887 \pm 4$ Ma (Trap et al., 2007). Importantly, monazite grains occur in the matrix, i.e. as inclusions within biotite, muscovite, quartz, as well as in staurolite and garnet rims but never in the garnet core. Trap et al. (2007) show that monazite crystallized during the prograde metamorphism in response to staurolite-in reaction and garnet breakdown as commonly observed in metapelite ( [Fitzsimons et al., 2005] , [Khon and Malloy, 2004] and [Spear and Pyle, 2002] ). The P-T-t-D path obtained through the forward modelling approach using garnet core composition (see Duguet et al., 2007) corresponds to the amphibolite facies prograde metamorphism coeval with the D1 deformation developed during nappe stacking at $1880 \mathrm{Ma}$.

\section{Geochronological data}

\subsection{Distinction of tectono-metamorphic periods from literature data}

\subsubsection{The $\sim 2.7$ Ga old basement}

Numerous geochronological studies documented inherited ages around $\sim 2.7 \mathrm{Ga}$ within the TNCO massifs, mainly in the Hengshan-Wutaishan-Fuping Massifs. Within the Northern Hengshan Massif, Kröner et al. (2005b) reported zircon SHRIMP U/Pb ages at $2701 \pm 5$ and $2670 \pm 1 \mathrm{Ma}$ from inherited zircon grains within a biotite gneiss, and $2712 \pm 2 \mathrm{Ma}, 2711 \pm 1$ Ma and $2697 \pm 1$ Ma ages within trondjhemitic rocks. Within the Wutaishan Massif, inherited zircon grains yield $\mathrm{U} / \mathrm{Pb}$ ages at $2679 \pm 16 \mathrm{Ma}$ and $2702 \pm 14 \mathrm{Ma}$ ( [Wilde et al., 2004a] , [Wilde et al., 2005] and [Wilde and Zhao, 2005] ). Within the Fuping Massif, ages at $2763 \pm$ $10 \mathrm{Ma}, 2660 \pm 7 \mathrm{Ma}$ and $2708 \pm 8 \mathrm{Ma}$ were also reported for inherited zircons within TTG gneiss ( [Guan et al., 2002] and [Wilde et al., 2005] ). These $\sim 2.7$ Ga ages might represent an old Neoarchean cratonic basement intruded by the subsequent $2.5 \mathrm{Ga}$ juvenile magmatism.

\subsubsection{The 2550-2450 Ma magmatism}

Most of the available U-Pb ages recorded within the Trans-North China Orogen range between 2550 and $2450 \mathrm{Ma}$ (e.g. [0135] , [Kröner et al., 2005a] , [Kröner et al., 2005b] , [Zhao et al., 2002b] , [Zhao et al., 2005] , [Zhao et al., 2006], [Wilde et al., 2004a] , [Wilde et al., 2005] and [Wilde and Zhao, 2005] ). All the recent geochronological investigations using $\mathrm{CL}$ imaging and zircon SHRIMP U-Pb dating revealed that the $\sim 2500 \mathrm{Ma}$ ages represent protoliths ages obtained on inherited grains or core of grains ( [Kröner et al., 2005a] , [Kröner et al., 2005b] , [Wilde and Zhao, 2005] , [Wilde et al., 2005] and [Zhao et al., 2005] ). These ages coming from orthogneiss are interpreted as those of the main magmatic activity that occurred in the NCC. This magmatism is interpreted whether as due to an arc activity ( [Zhang et al., 2009] and [Zhao et al., 2005] ) or alternatively as the result of the collision of the Western and Eastern Blocks along the Central Orogenic belt to form a coherent craton at $\sim 2.5 \mathrm{Ga}$ (Kusky and Li, 2003). 


\subsubsection{The $\sim 2.1$ Ga Ma thermal and magmatic event}

A large pool of $\mathrm{U}-\mathrm{Pb}$ ages, ranging from $2.3 \mathrm{Ga}$ to $2.0 \mathrm{Ga}$, was reported in the different TNCO massifs. In particular, the dates obtained from plutonic and volcanic rocks in the Hengshan, Wutaishan and Fuping Massifs argue for a tectono-thermal event around $2.1 \mathrm{Ga}($ [Geng et al., 2000], [Peng et al., 2005] , [Trap et al., 2008], [Wilde et al., 1998], [Wilde et al., 2005] , [Wilde and Zhao, 2005] , [Yu et al., 1997] and [Zhao et al., 2002b] ). One gabbroic rock enclosed in migmatitic gneiss from the lower part of the OVU, south of the HPB, yielded a SHRIMP U-Pb age at $2193 \pm 15 \mathrm{Ma}$ (Wang et al., 2010a). Intense 2.0-2.1 Ga magmatism is also recorded in the para-autochthonous domain (i.e. the Fuping Massif). Trap et al. (2008) interpreted the 2.0-2.1 Ga ages in the Fuping Massif as an indication of a regional tectono-thermal event responsible for partial melting of the TTG crust and anatectic plutonism. This view is in agreement with Cheng et al. (2001) that reported and interpreted three TIMS U-Pb zircon ages at $\sim 2.06-2.08 \mathrm{Ga}$ as anatectic ages within migmatite from the Fuping Massif. Within the High-Pressure Belt, evidence for this event comes from a fine grained orthogneiss, a granite-gneiss, and a trondhjemitic gneiss dated at $2358.7 \pm 0.5,2331 \pm$ 36, $2329.7 \pm 0.6 \mathrm{Ma}$, respectively (Kröner et al., 2005b). Three felsic granitoids, one pegmatite and one anatectic granite have also been reported by Kröner et al. (2005b) at 2248.5 $\pm 0.5 \mathrm{Ma}$ and $2113 \pm 8 \mathrm{Ma}$, respectively. Within the Huai'an massif, some ages around 2100 $\mathrm{Ma}$ are also reported from Al-rich metasediments and some granitoids such as the Dongjiagou gneissic granite dated at $2036 \pm 19 \mathrm{Ma}$ (Zhao et al., 2008).

\subsubsection{The $1950-1920 \pm 10$ Ma period: time of HT-UHT metamorphism}

In the southern part of the HPB, two sets of magmatic zircons from two mafic high-pressure granulites yielded mean ${ }^{207} \mathrm{~Pb} /{ }^{206} \mathrm{~Pb}$ ages of $1915 \pm 4$ Ma and $1914 \pm 2 \mathrm{Ma}$, respectively, interpreted as reflecting the time of the magmatic emplacement of the HP-granulites gabbroic dyke precursors (Kröner et al., 2006). Similar 1915 Ma ages were reported in two metapelites of the southwestern located Lüliang Massif (Trap et al., 2009b). Based on SHRIMP U-Pb zircon dating, Santosh et al. (2007b) suggest an age of metamorphism in the HT to UHT granulite facies at $\sim 1920$ Ma.

\subsubsection{The $1880 \pm 10$ Ma period: time of peak metamorphism during crustal thickening}

Within the OVU, a chemical U-Th-Pb analysis of monazite from a kyanite-bearing metapelite yielded an age of $1883 \pm 11$ Ma (Faure et al., 2007). Trap et al. (2007, this study) interpreted the concordant $\mathrm{U}-\mathrm{Th}-\mathrm{Pb}$ monazite ages of $1887 \pm 4 \mathrm{Ma}, 1886 \pm 5 \mathrm{Ma}$ and $1884 \pm$ $11 \mathrm{Ma}$ from three metapelites located in the southern adjacent OVU unit as the age of the prograde amphibolite facies metamorphism coeval with nappe-stacking. In the Xuanhua Massif, Guo et al. (2005) obtained a zircon SHRIMP U-Pb age at $1872 \pm 16$ from the highpressure granulites. We interpret the 1870-1890 Ma period as the time of peak metamorphism coeval with nappe-stacking and crustal thickening during D1 event. In addition, the age of $1872 \pm 17$ recorded in a migmatitic leucosome of granitic composition (Kröner et al., 2005b) might correspond to the onset of partial-melting in response to crustal thickening, in agreement with Zhang et al. (1994) that postulated that melt was present at peak-assemblage conditions during the 1870-1890 Ma period. SHRIMP U-Pb ages of metamorphic zircons of $1881 \pm 8 \mathrm{Ma}$ and a mean evaporation ${ }^{207} \mathrm{~Pb} /{ }^{206} \mathrm{~Pb}$ age of $1881.3 \pm 0.4 \mathrm{Ma}$ have been reported in the Hengshan migmatites ( [Kröner et al., 2005a] and [Kröner et al., 2006] ). 


\subsubsection{The $1850 \pm 10$ Ma period: time of widespread crustal melting}

Zircon conventional U-Pb multigrain and SHRIMP U-Pb dating, in particular within the HPB and surrounding units yield pooled ages around $1850 \mathrm{Ma}$ ( [Faure et al., 2007] , [0135] , [Kröner et al., 2005a], [Kröner et al., 2005b] , [Wan et al., 2006] , [Wang et al., 2010b], [Wilde and Zhao, 2005] , [Zhao et al., 2002b] , [Zhao et al., 2005] and [Zhao et al., 2006] ). In the Hengshan Massif, Kröner et al. (2005b) obtained metamorphic zircon U-Pb ages of 1848 $\pm 51850 \pm 3,1867 \pm 23,1859.7 \pm 0.5 \mathrm{Ma}$ from the high-grade granitoid gneisses and highpressure mafic granulites. An ICP-MS U-Pb age at $1850 \pm 5$ Ma from metamorphic zircons rims of an anatectic leucosome has been interpreted to date partial-melting (Faure et al., 2007). In the Datong-Huai' an area, SHRIMP U-Pb dating of magmatic zircon from an anatectic charnockite and a granite (Dapinggou pluton), yield ages of $1849 \pm 9.8 \mathrm{Ma}$ and 1850 $\pm 17 \mathrm{Ma}$, respectively (Zhao et al., 2008). Furthermore, the metamorphic zircons from TTG gneisses, Paleoproterozoic granitoids and khondalitic rocks yield similar concordant ${ }^{207} \mathrm{~Pb} /{ }^{206} \mathrm{~Pb}$ ages around $1850 \mathrm{Ma}$, coeval with the emplacement of the Huai'an anatectic charnockite and Dapinggou syn-collisional granite (Zhao et al., 2008). Therefore we interpret the numerous $1850 \pm 10 \mathrm{Ma}$ ages as the date of the period corresponding to the peak of crustal melting and related anatectic plutonism. This is in agreement with Wang et al. (2010b) that compiled metamorphic zircon ages for high-grade metamorphic rocks from the whole TNCO and revealed three age peaks at $1876 \pm 6 \mathrm{Ma}, 1849 \pm 2 \mathrm{Ma}$ and $1814 \pm 4 \mathrm{Ma}$. These authors proposed that $1845 \pm 7 \mathrm{Ma}$ is the best estimate for the timing of the HP metamorphism in the Huai' an Massif. In the light of this compilation we rather suggest that the $1845 \mathrm{Ma}$ age corresponds to the peak partial-melting and magmatism that post-date the pressure peak clearly settled at ca. 1880 Ma.

\subsubsection{The $<1850$ Ma ages}

Within the HPB, a set of zircon U/Pb ages around $1820 \pm 20 \mathrm{Ma}$ is recorded in a charnockite pluton and some granulites blocks ( [Guo et al., 1993] and [0135] ). Rimmed zircons from a migmatitic leucosome recorded a magmatic core at $1846 \pm 21 \mathrm{Ma}$ and a metamorphic rim at $1819 \pm 13 \mathrm{Ma}$ (Wang et al., 2010b). The above presented litho-tectonic units are intruded by several generations of undeformed granitoids, such as the large granodioritic and monzogranitic Guandishan pluton and the enderbitic-monzonitic Lüyashan pluton in the southern and northern parts of Lüliangshan, respectively (Fig. 2). These plutons yield U-Pb ages around 1820-1800 Ma ( [Geng et al., 2000], [Geng et al., 2004] and [Yu et al., 2004] ). Finally, a pegmatite dyke at $1806 \pm 15$ (Wang et al., 2010b) is similar in age to the unstrained post-tectonic granites.

\subsection{New ${ }^{40} \mathrm{Ar} /{ }^{39} \mathrm{Ar}$ dating of some Hengshan and Wutaishan rocks}

In this section we present new ${ }^{40} \mathrm{Ar} /{ }^{39} \mathrm{Ar}$ ages obtained on some rocks within the Wutaishan and Hengshan Massifs. Five groups of ${ }^{40} \mathrm{Ar} /{ }^{39} \mathrm{Ar}$ ages have been obtained and are discussed in the framework of the tectono-metamorphic events described above.

\subsection{1. ${ }^{40} \mathrm{Ar} /{ }^{39} \mathrm{Ar}$ dating method}

${ }^{40} \mathrm{Ar} /{ }^{39} \mathrm{Ar}$ dating was performed at the University of Montpellier II, France. The analytical procedure for laser probe dating is similar to that fully described by Dalrymple (1989). It consists of a continuous $\mathrm{CO}_{2}$ laser connected to a MAP 215-50 mass spectrometer. Irradiation of amphibole and mica grains $(0.5 \mathrm{~mm}$ in diameter) was performed with several $\mathrm{MMHb}$ 
monitor grains (Samson and Alexander, 1987) in the McMaster nuclear reactor (Canada) for $70 \mathrm{~h}$. After irradiation, the grains were placed within a low-volume, high-vacuum extraction line and stepwise heated with the laser beam. The age determination required approximately $20 \mathrm{mn}$ for lasering, gas cleaning and data acquisition. Blanks, monitored every two or three experiments were about $6 \times 10^{-17}, 5 \times 10^{-19}, 1.5 \times 10^{-18}, 1 \times 10^{-17}$ and $3 \times 10^{-18}$ mol for masses 40, 39, 38, 37 and 36, respectively. Additional details concerning our experimental procedure are given in [Monié et al., 1994] and [Monié et al., 1997] .

\subsection{2. ${ }^{40} \mathrm{Ar} /{ }^{39} \mathrm{Ar}$ dating results}

Three rock samples, FP40, FP108 and FP185 yield similar ages at $1804 \pm 13 \mathrm{Ma}, 1802 \pm 13$ Ma and $1799 \pm 12$ Ma, respectively (Fig. 9). The rock FP40 is an undeformed quartz + plagioclase + muscovite granitic dyke that cross-cuts the $S 1-2$ amphibolite facies foliation along the Zhujiafang Shear Zone (Fig. 8; N39²4.478'/E113³5.834'). A muscovite grain yields a plateau age of $1804 \pm 13 \mathrm{Ma}$ for about $55 \%$ of the gas released (Fig. 9a). The rock FP108 is a garnet-bearing gneiss sampled in the upper part of the OVU (Fig. 8; $\left.\mathrm{N} 39^{\circ} 06.679^{\prime} / \mathrm{E} 113^{\circ} 14.419^{\prime}\right)$. A biotite grain gives a plateau age at $1802 \pm 13 \mathrm{Ma}$ for more than $60 \%$ of argon released (Fig. 9b) with an evidence of partial argon loss during first heating steps. The rock FP185 is a meta-rhyolite sampled above the Upper Wutai Thrust (Fig. $\left.9 \mathrm{c} ; \mathrm{N} 39^{\circ} 04.060^{\prime} / \mathrm{E} 113^{\circ} 39.679^{\prime}\right)$. The rock is composed by millimeter-size plagioclase and biotite porphyroclasts within a fine grained quartz + muscovite + plagioclase matrix. A biotite grain gives a plateau age of $1799 \pm 13 \mathrm{Ma}$ for $\sim 80 \%$ of argon released. The $1800 \mathrm{Ma}$ ages recorded by these three samples can be correlated to the $1800 \mathrm{Ma}$ old plutonic event responsible for the emplacement of the post-orogenic undeformed granitic plutons in the area. The granitic dyke FP40 is an evidence of this post-orogenic activity. Consequently, the ${ }^{40} \mathrm{Ar} /{ }^{39} \mathrm{Ar}$ age recorded in metamorphic rocks FP108 and FP185 could reflect the thermal effect related to the emplacement of such post-orogenic magmas.

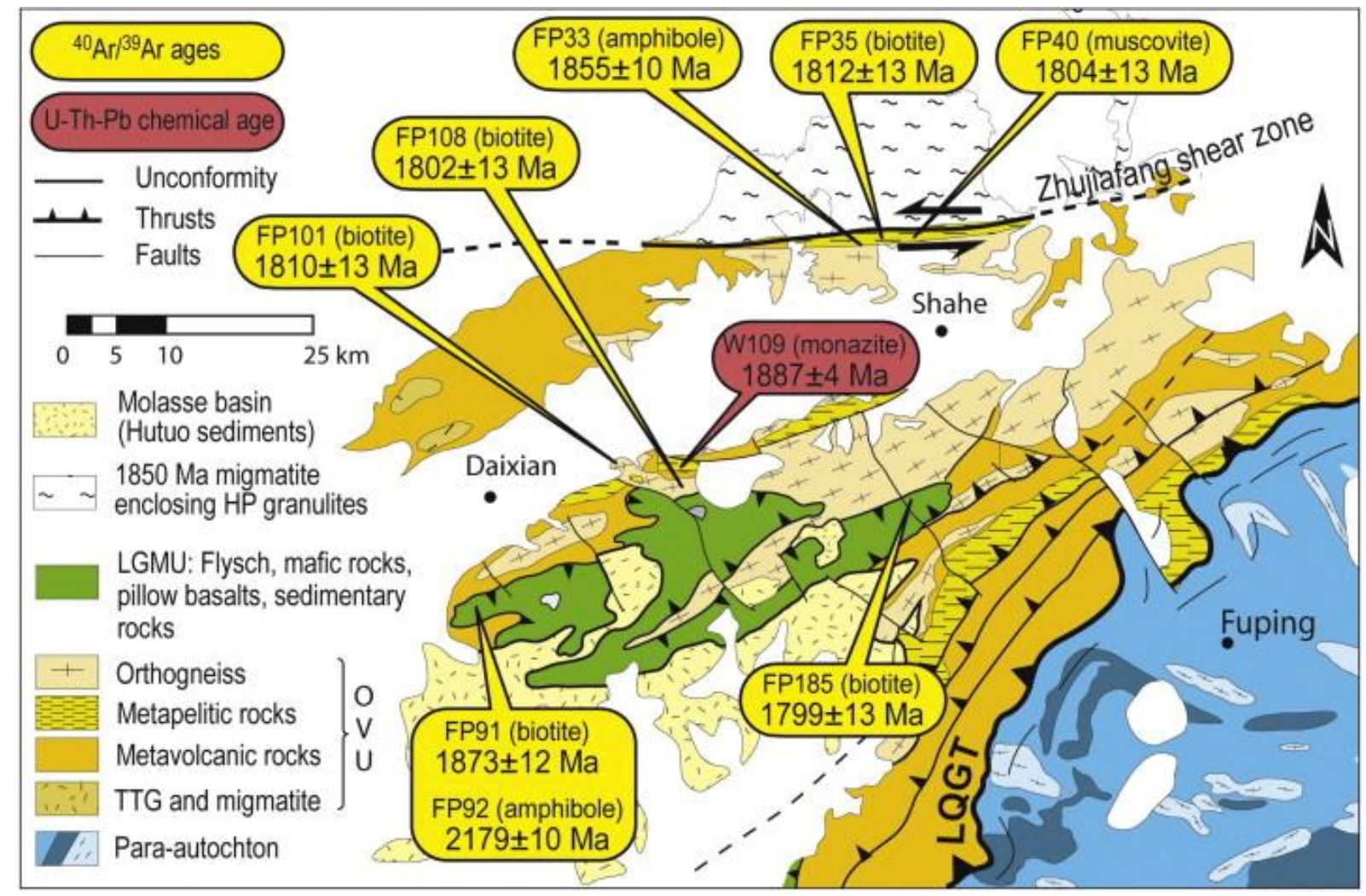


Fig. 8. : Lithotectonic map of the central TNCO area with location of the samples used for petrological and ${ }^{40} \mathrm{Ar} /{ }^{39} \mathrm{Ar}$ investigations.
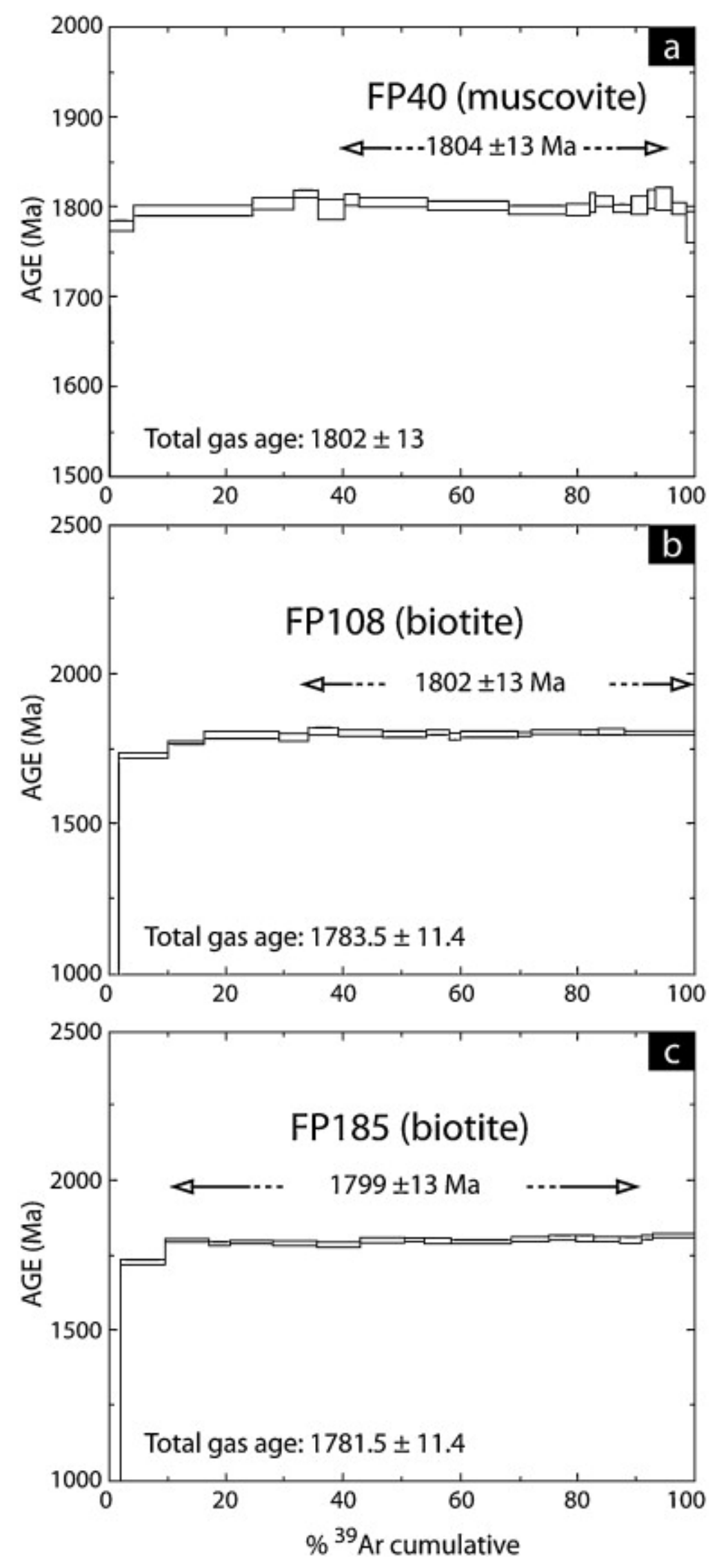
Fig. 9. : ${ }^{40} \mathrm{Ar} /{ }^{39} \mathrm{Ar}$ age spectra calculated at $2 \sigma$ for samples FP40 (a), FP108 (b), FP185 (c). Corresponding analyses are given in Appendix F (Supplementary data).

A second set of slightly older ages around $1810 \mathrm{Ma}$ is obtained for two rocks (FP35 and FP101) from different localities. Rock FP35 is a gneissic metapelite from the OVU with a quartz + plagioclase + biotite + grenat + kyanite + staurotide assemblage, sampled along the Zhujiafang strike-slip shear zone (Fig. 8; N39 $23.743^{\prime} / \mathrm{E}^{\circ} 13^{\circ} 35.831^{\prime}$ ). A biotite grain yields a plateau age at $1812 \pm 10 \mathrm{Ma}$ for $55 \%$ of the gas released (Fig. 10a). The first heating steps record younger ages possibly due to a thermal overprint or to some alteration process (Turner, 1968). The rock FP101 comes from the Ekou orthogneiss, which is located in the northern edge of the Wutaishan Massif (Fig. 8;

$\left.\mathrm{N} 39^{\circ} 07.611^{\prime} / \mathrm{E} 113^{\circ} 12.165^{\prime}\right)$. The sample is a well foliated biotite + quartz + feldspath gneiss. The fabric is defined by a subvertical mylonitic foliation trending $\mathrm{N} 80 \mathrm{E}$ that holds a pronounced mineral lineation that plunges $10^{\circ}$ to the east. A biotite grain yields a plateau age at $1810 \pm 13 \mathrm{Ma}$ in the intermediate portion of the spectrum (Fig. 10b), with younger ages on both sides possibly reflecting mixture effects with chlorite (Di Vincenzo et al., 2003). These two samples that show similar ${ }^{40} \mathrm{Ar} /{ }^{39} \mathrm{Ar}$ cooling ages at $1810 \mathrm{Ma}$ are also defined by the same relatively low-temperature strike-slip fabrics that is not observed in the other samples. Consequently, given the closure temperature for argon in biotite $\left(\sim 320^{\circ} \mathrm{C}\right.$, Harrison et al., 1985), the 1810 and 1812 Ma ages might represent the age of strikeslip deformation recorded in northern Wutaishan and along the Zhujiafang Shear Zone. These two ages are very close to the $\sim 1800 \pm 13$ Ma ages recorded by the first sample set. However, the field relationships with the FP40 granitic dyke secant cutting the ZSZ foliation argue for a distinction of the two events. 


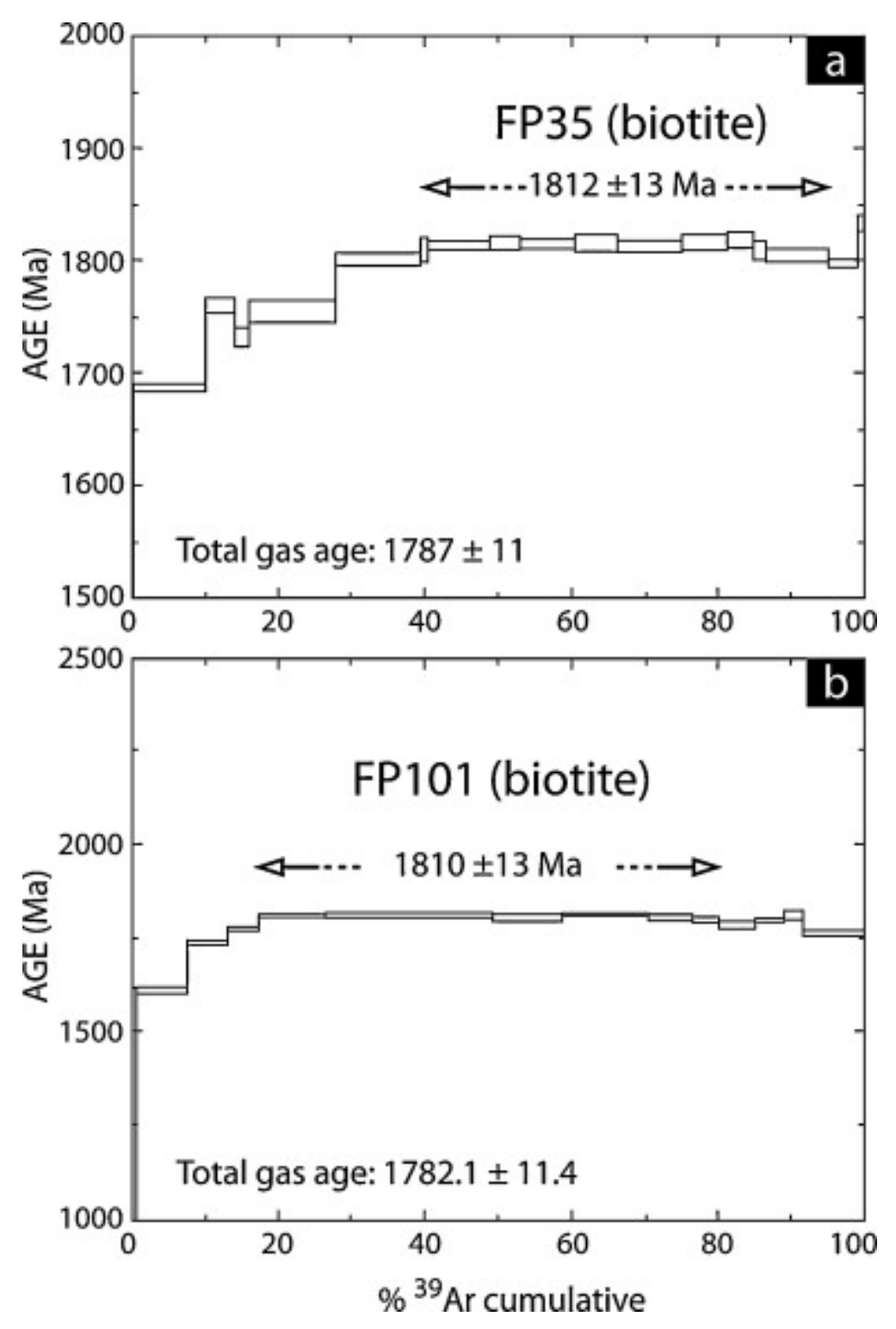

Fig. 10. : ${ }^{40} \mathrm{Ar} /{ }^{39} \mathrm{Ar}$ age spectra calculated at $2 \sigma$ for samples FP35 (a), FP101 (b). Corresponding analyses are given in Appendix F (Supplementary data).

The sample FP33 comes from the Yixingzhai dioritic gneiss (Fig. 8;

$\left.\mathrm{N} 39^{\circ} 22.351^{\prime} / \mathrm{E} 113^{\circ} 35.748^{\prime}\right)$ and shows an assemblage of quartz + plagioclase + amphibole + biotite. An amphibole grain yields a saddle-shaped spectrum with an age of $1855 \pm 10 \mathrm{Ma}$ at intermediate temperature (Fig. 11a). The homogenous ${ }^{37} \mathrm{Ar} /{ }^{39} \mathrm{Ar}$ ratio, and the heterogeneous ${ }^{38} \mathrm{Ar} /{ }^{39} \mathrm{Ar}$ one suggest that some excess argon is responsible for the shape of the age spectrum (Fig. 11a, Appendix F). The Yixingzhai dioritic gneiss suffered partial melting, and textural analyses show evidence for high-temperature deformation (Trap et al., 2007). Therefore, and because of the relatively high closure temperature for argon in amphibole $\left(\sim 550-600{ }^{\circ} \mathrm{C}\right.$, Dahl, 1996), the age of $1855 \mathrm{Ma} \pm 10 \mathrm{Ma}$ is interpreted as related to the end of migmatization event and coeval deformation that affected a large part of the Hengshan Massif around 1850 Ma ( [Faure et al., 2007], [Trap et al., 2007] and [Trap et al., 2011] ). 

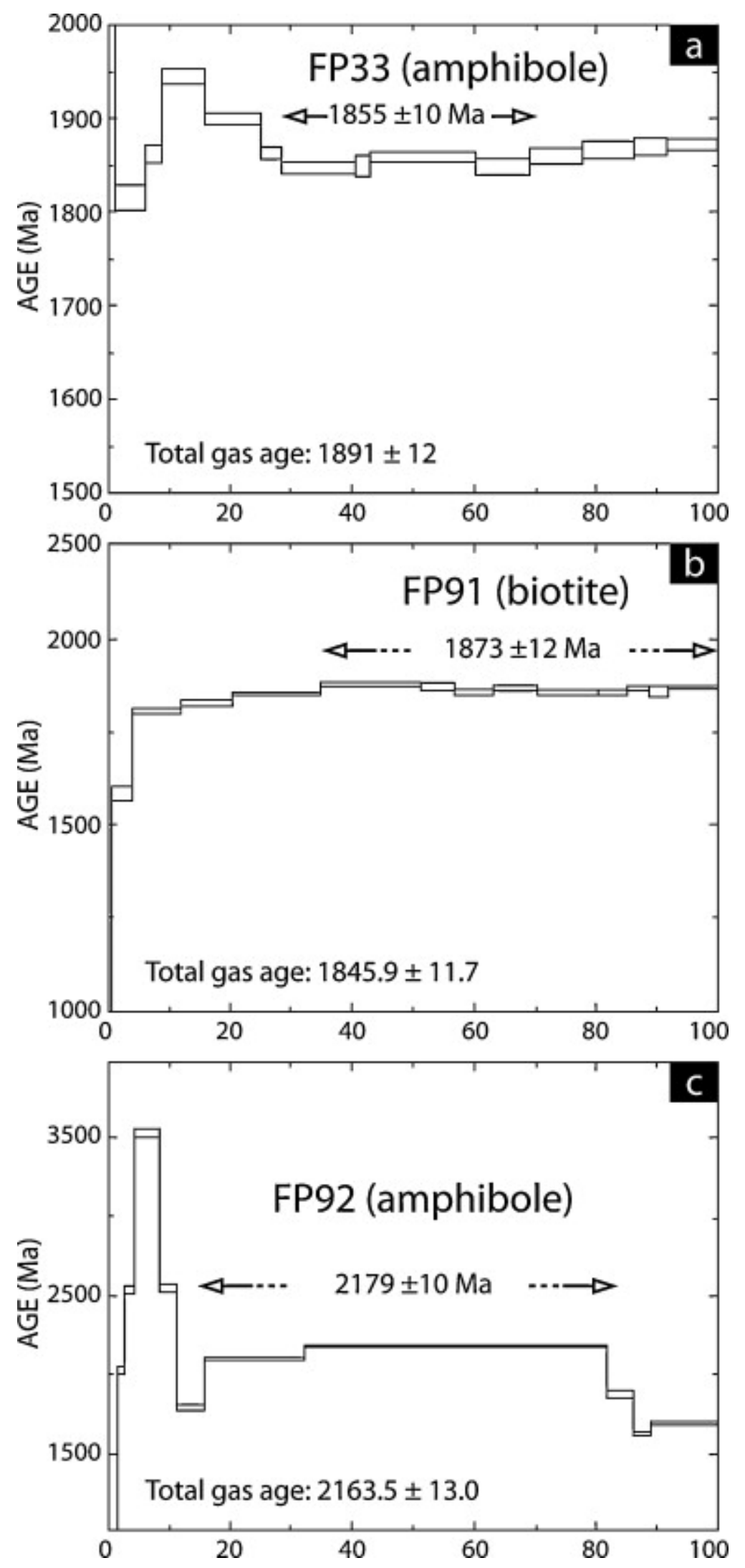

Fig. 11. : ${ }^{40} \mathrm{Ar} /{ }^{39} \mathrm{Ar}$ age spectra calculated at $2 \sigma$ for samples FP33 (a), FP91 (b), FP92 (c). Corresponding analyses are given in Appendix F (Supplementary data) 
The rock FP91 is a biotite + garnet + chlorite \pm plagioclase \pm epidote retrograded micaschist, tectonically interleaved with mafic schist within the LGMU (Fig. 8;

$\mathrm{N} 38^{\circ} 57.398^{\prime} / \mathrm{E} 112^{\circ} 59.172^{\prime}$ ) along the Upper Wutai Thrust. A biotite grain yields a plateau age of $1873 \pm 13 \mathrm{Ma}$ (Fig. 11b), with some evidence of argon loss at low experimental temperature. Considering the $320{ }^{\circ} \mathrm{C}$ closure temperature for argon in biotite, this plateau age can be correlated to the end of the general $\sim 1880 \pm 10$ Ma syn-D1 barrovian metamorphic event that corresponds to crustal thickening during nappe stacking ( [Trap et al., 2007] , [Trap et al., 2009b] , [Wilde et al., 2002] and [Zhao et al., 2002b] ). Nevertheless, these data suggest that rocks from the LGMU experienced fast cooling after peak metamorphic conditions were reached.

Finally, the older ${ }^{40} \mathrm{Ar} /{ }^{39} \mathrm{Ar}$ age is obtained for the rock FP92, which is a metagabbro with a hornblende + plagioclase + epidote + pyroxene + quartz assemblage, sampled about $10 \mathrm{~m}$ above rock FP91 (N39 $\left.23.743^{\prime} / \mathrm{E} 112^{\circ} 35.831^{\prime}\right)$. A magmatic hornblende grain, which is partially replaced by secondary amphibole and chlorite, yields a discordant age spectrum from which a mean age of $2179 \pm 10$ Ma can be calculated for its intermediate portion (Fig. 11c). The complexity of this spectrum (Fig. 11c), correlated with strong variations in ${ }^{37} \mathrm{Ar}{ }^{39} \mathrm{Ar}$ et ${ }^{38} \mathrm{Ar} /{ }^{39} \mathrm{Ar}$ ratios (Appendix F), might be related to chemical heterogeneities within the grain, and to excess argon released at low temperature and probably trapped during the metamorphic overprint. As a hypothesis, the age of $2179 \pm 10 \mathrm{Ma}$ might be considered as the minimum age for emplacement of the gabbro. Additional data would be useful to better settle this event.

\section{Discussion}

\subsection{About some controversial points}

\subsubsection{Polarity of subduction}

Three of the models reviewed in Section 3 agree to favor a westward subduction for the TNCO ( [Faure et al., 2007] , [Kusky, 2011], [Trap et al., 2007] , [Wang, 2009] and [Wang et al., 2010a] ). In contradiction with these authors, the model 1 (e.g. [Zhao et al., 1998] and [Zhang et al., 2007] ) argues for an eastward subduction in order to explain the continental arc that developed on the western margin of the Eastern Block. Recently, the new seismic reflection and tomographic data completed across the TNCO highlighted the shear-wave velocity structure of the crust and uppermost mantle. Based on the work of Zheng et al. (2009), Trap et al. (2009a) interpreted the offset of the seismic velocity layers in the crust as the mark of an east-directed discontinuity that could be related to a north-west-directed subduction. These geophysical data were also put forward as a strong argument for a westward subduction polarity previously deduced from field work in models 2, 3, and 4 (i.e. [Kusky, 2011] and [Santosh, 2010] ).

\subsubsection{Age of TNCO collision and NCC amalgamation}

The building of the TNCO through collision, and the resulting amalgamation of the North China Craton is thought to have occurred at $\sim 2.5 \mathrm{Ga}$ (model 2: e.g. [Kusky, 2011] and [Kusky and Li, 2003] ) or at $\sim 1.85 \mathrm{Ga}$ (models 1, 3 and 4: e.g. [Faure et al., 2007] , [Wang et al., 2010a] and [Zhao et al., 2004b] ). Faure et al. (2007) suggested that since both pluton generations $(2.5 \mathrm{Ga}$ and $2.1 \mathrm{Ga})$ are converted into orthogneiss, the tectonic events responsible for the main deformation in the OVU must be younger than $\sim 2.1 \mathrm{Ga}$. Indeed, the finite strain patterns that define the TNCO structural features were constrained in time 
between 1.9 and $1.8 \mathrm{Ga}$ ( [Faure et al., 2007] , [Trap et al., 2007] , [Zhang et al., 2007] and [Liu et al., 2010] ). In particular, the D1 top-to-the E-SE directed nappe stacking responsible for crustal thickening is clearly related to the 1.9-1.8 period (Trap et al., 2007, this study). Furthermore, the newly discovered detrital zircon ages of some Hutuo Supergroup sedimentary rocks around 1.88-1.81 Ga ( [Liu et al., 2010] , [Liu et al., 2011a] and [Liu et al., $2011 \mathrm{~b}]$ ) support the collision between the Eastern and Western Blocks at $\sim 1.85 \mathrm{Ga}$.

Therefore, we suggest that collisions responsible for the Trans-North China Orogen and final amalgamation of the North China Craton occurred more likely at $\sim 1.85 \mathrm{Ga}$, not at $\sim 2.5 \mathrm{Ga}$.

\subsection{3. "Ancient accretionary-type" versus "modern collisional-type"}

The four current models invoked for the TNCO show contrasting views concerning the type of orogen, namely continent-continent collisional-type versus accretionary-type. This distinction is worth to consider, in particular for the case of the highly debated TNCO, but it needs however some specifications. By distinguishing "accretionary-type" versus "collisionaltype", one may consider the geodynamic settings, lithospheric rheological behaviours and crustal deformation patterns that are different between these two orogenic-type end-members ( [Cagnard et al., 2011] and [Chardon et al., 2009] ). A collisional-type orogen involves continental blocks with a stiff lithosphere whereas the accretionary-type orogen involves a hot and weak lithosphere due to participation of juvenile magmatic material in the orogenic crustal thickening (see Cagnard et al., 2011 and references therein).

In the TNCO, the peak of juvenile magmatic crust occurred at $\sim 2.5 \mathrm{Ga}$ and is largely documented in the Hengshan-Wutaishan-Fuping Massifs that yield Kusky and Li (2003) to argue for a major collisional event responsible for the amalgamation of the NCC during this period. In the TNCO, the $\sim 2.5 \mathrm{Ga}$ TTG granitoids are interpreted as the result of partial melting of a mantle source ( [Wang, 2009] and [Wang et al., 2010a] ) giving rise to a juvenile crust (Zhao, 2010). As highlighted by Wang et al. (2010a), no arc-type juvenile magmatism younger than $\sim 2.1 \mathrm{Ga}$ has ever been discovered in the Lüliang-Hengshan-Wutaishan-Fuping area. Moreover, the $\sim 2.5 \mathrm{Ga}$ ages are not strictly limited to the TNCO, but are also homogeneously distributed within the entire NCC (Zhao et al., 2005). Such $\sim 2.5$ Ga ages are largely reported among the TTG gneiss from the Eastern and Western Blocks, where domeand-basins geometry predominates (Zhao et al., 2001a) with gneissic domes (5-60 km long and 2-40 km width) and a network of anastomosed basins filled with supcracrustal rocks ( [Sun et al., 1993] , [Bai and Dai, 1998] and [Choukroune et al., 1993] ). Such a domes-andbasins geometry is largely predominant within Precambrian orogens inferred to have developed after collision involving hot and weak lithosphere, such as expected in accretionary contexts involving juvenile material (see Cagnard et al., 2011 and references therein). This domes-and-basins pattern is accompanied by (i) distributed thickening coeval with homogeneous metamorphic grades over wide areas; (ii) combination of domains with flatlying fabrics and domains with sub-vertical shear zones and (iii) erosion driven exhumation ( [Cagnard et al., 2006] , [Cagnard et al., 2007] , [Cagnard et al., 2011] , [Cruden et al., 2006] and [Vidal et al., 2009] ; see Chardon et al., 2009 and references therein). Considering these tectonic features, we propose that the $\sim 2.5 \mathrm{Ga}$ event responsible for the emplacement of the Wutai granitoids may correspond to an accretionary-type orogen involving juvenile magmatism. However, the main tectonic features of this $\sim 2.5 \mathrm{Ga}$ old orogenic system, in particular the architecture of the belt(s) and its boundaries remain unknown.

As outlined by Cagnard et al. (2011), conversely to accretionary-type orogens, modern (i.e. Phanerozoic) collisional orogens such as the Himalayas or the Alps are defined by a colder 
and stiffer lithosphere. Consequently, the orogenic style exhibits (i) juxtaposition of tectonometamorphic units with contrasting metamorphic grades; (ii) nappe stacking along lithospheric-scale thrusts; (iii) syn-orogenic detrital sedimentary basins; and (iv) syn- and post-thickening extension with crustal-scale detachments (v) tectonically driven exhumation of HP/UHP metamorphic rocks ( [Gapais et al., 2009] and [Cagnard et al., 2011] ). All these typical features are indeed reported within the TNCO that can be therefore considered as typical collisional-type orogen. This is a further argument to assert that the TNCO did not formed at $\sim 2.5 \mathrm{Ga}$ but at $\sim 1.85 \mathrm{Ga}$. In agreement with Zhao (2010) we suggest that the 1.9$1.8 \mathrm{Ga}$ Trans-North China Orogen is responsible for the amalgamation of the NCC, but we consider that the two orogenic evolutions at $2.5 \mathrm{Ga}$ and $1.9-1.8 \mathrm{Ga}$ are unrelated.

\subsubsection{Significance of the $\sim 2.1$ Ga tectono-thermal event}

Within the TNCO, a large pool of ages ranges from $2.3 \mathrm{Ga}$ to $2.0 \mathrm{Ga}$ that mainly represent a magmatic activity well documented in the Wutaishan and Fuping Massif ( [Guan et al., 2002] , [Wilde et al., 2004a] , [Wilde et al., 2004b] and [Zhao et al., 2002b] ). However, this event is not only a magmatic one but also a tectonic one since in the Fuping Massif, the domes-andbasins architecture formed in response to a regionally coaxial deformation defined by crustal $\mathrm{N}-\mathrm{S}$ horizontal shortening and $\mathrm{E}-\mathrm{W}$ horizontal stretching, contemporaneous with a largescale thermal event (Trap et al., 2008). According to structural, geochronolgical and geochemical signatures, most of models are in accordance for considering the $2.3-2.1 \mathrm{Ga}$ tectono-magmatic activity as a rifting period (models 2, 3 and 4; e.g. [Faure et al., 2007], [Trap et al., 2009b] , [Wang, 2009] , [Wang, 2010] , [Wang et al., 2010a] and [Kusky, 2011] ). The age ${ }^{40} \mathrm{Ar} /{ }^{39} \mathrm{Ar}$ age of $2179 \pm 10 \mathrm{Ma}$ obtained from a metagabbro of the LGMU (this study) could attest for ocean basin development at ca. 2.2 Ga. This age is consistent with the zircon SHRIMP U/Pb age of a gabbro of the Yanmenguan mafic-ultramafic intrusion at 2193 $\pm 15 \mathrm{Ma}$ (Wang et al., 2010a). Recently, new LA-ICP-MS U/Pb datings yield Zhang et al. (2011) to consider some ca. 2000 Ma syenogranites were emplaced together with mafic dikes during intraplate rifting that resulted in basins formation. Zhai and Santosh (2011) also attest a rifting stage in the NCC (here called proto-NCC) occurred at 2300-2000 Ma with the formation of ancient remnant ocean basins. In our model (see Section 8.2), we shall consider that the rifting that took place from 2.3 to $2.0 \mathrm{Ga}$ is responsible for the opening of two oceanic domains, the Taihang and Lüliang Oceans, which resulted in the breakup of the proto-NCC.

\subsubsection{Significance of the 1.9-1.8 Ga metamorphism}

Kusky and Li (2003; model 2) suggested that the global N-S trend of D1 structures in the Hengshan-Wutaishan-Luliangshan Massifs developed during the Neoarchean, whereas the 1.9-1.8 Ga metamorphism is related to the tectonic events that occurred along the $1400 \mathrm{~km}$ long Paleoproterozoic to Mesoproterozoic Inner Mongolia-Hebei Orogenic belt (IMHO), which is located $200 \mathrm{~km}$ north, along the northern edge of the NCC. When correlated with the deformation and available geochronological data (Trap et al., 2007), the metamorphic P-T conditions provide the first thermo-barometric quantitative constraints on the $\mathrm{P}-\mathrm{T}-\mathrm{t}-\mathrm{D}$ path, of the D1/M1 prograde deformation and metamorphic event within a segment of the TNCO (this study). The prograde evolution is defined by a $4 \mathrm{kbar}$ minimum pressure increase that corresponds to a burial of more than $10 \mathrm{~km}$. This burial is clearly associated with a top-to-the SE D1 shearing. Therefore, and in agreement with models 1, 3 and 4 (e.g. [Zhao et al., 2005] , [Trap et al., 2007] and [Wang, 2009] ), the 1.9-1.8 Ga metamorphism in the TNCO cannot be interpreted as a metamorphic overprint related to the E-W trending IMNHO. 


\subsection{A possible tectonic model for the Trans-North China Orogeny}

As mentioned previously our model involves three Archean continental blocks, the Western, Fuping and Eastern Blocks that were separated by the Lüliang and Taihang Oceans before their welding during the Paleoproterozoic Lüliangian Orogeny. Our recent work (Trap et al., 2011) together with new advances on NCC, lead us to propose a new improvement of the early model proposed by Faure et al. (2007) and [Trap et al., 2007] , [Trap et al., 2008] , [Trap et al., 2009a] , [Trap et al., 2009b] and [Trap et al., 2011] that accounts for the evolution of the Trans-North China Orogen and the North China Craton, from the Neoarchean to the Late Paleoproterozoic times (Fig. 12).

W

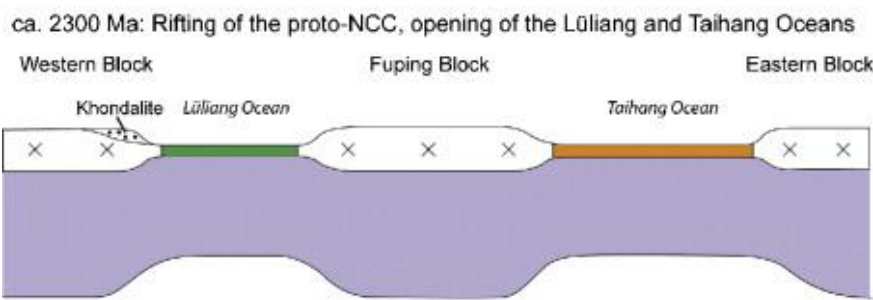

ca. $2150 \mathrm{Ma}$ : Closure of the Taihang ocean, formation of the Wutaihsan Arc

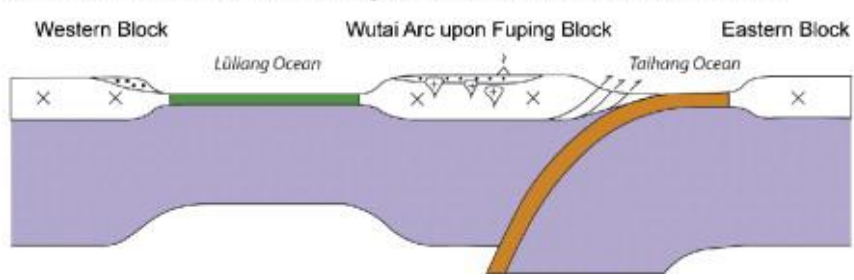

W

ca. 1900-1860 Ma: Collisions and amalgamation of the NCC

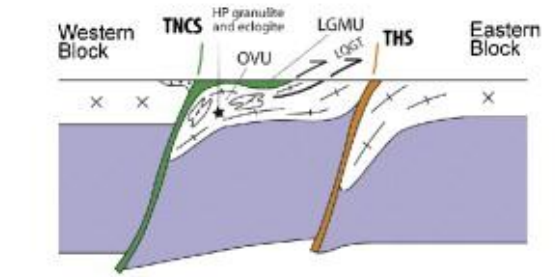

ca. 1860-1800 Ma: Deposition of Hutuo Group, late orogenic folding, anatexis, HP rocks exhumation and post-orogenic plutosnism

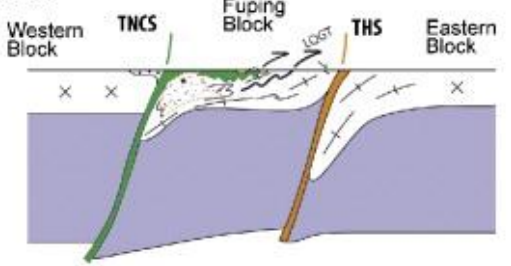

Fig. 12.

Schematic cartoon of a possible geodynamic evolution of the TNCO from the $2.3 \mathrm{Ga}$ rifting of the proto-NCC toward the 1.9-1.8 Ga welding of the NCC.

In agreement with Zhao et al. (2010), and due to the existence of 2.7 Ga xenocrystic zircons in the Wutaishan granitoids we might favor the model of a continental arc to explain the 2.5 Ga magmatism within the Central North China Craton area. However, in our present state of knowledge, we suggest that the tectonic features of the $2.5 \mathrm{Ga}$ event are too poorly constrained. In our view, the $2.5 \mathrm{Ga}$ event has to be regarded as disconnected from the events operating in the period 2.1-1.8 Ga, which are related to the Trans-North China Orogeny. In our model, we consider that a proto-North China Craton, of unknown regional extension, was amalgamated by the end of the 2.5 event.

Rifting at $\sim 2.3 \mathrm{Ga}$ was responsible for the breakup of this proto-NCC and individualization of the Eastern, Fuping and Western Blocks, that will be subsequently welded together to form the TNCO. During the 2.3-2.1 period, the Lüliang and the Taihang oceanic basins formed in response to rifting of the $\sim 2.5 \mathrm{Ga}$ old proto-NCC. The Taihang oceanic basin might developed first and began to subduct westward under the Fuping Block. The Taihang suture is now exposed in the Zanhuang massif (Trap et al., 2009b). Simultaneously, the Lüliang Ocean formed as a marginal back-arc basin coeval with the development of the OVU ( [Faure et al., 2007] and [Wang et al., 2010a] ). Our structural studies suggest that the Lüliang Ocean closed due to the westward subduction of the Fuping Block below the Western Block (represented 
west of Lüliangshan by the Ordos Block). The crust and oceanic sediments of the Lüliang Ocean are presently preserved mainly in the Low-Grade-and-Mafic Unit. Two collisions between the Western and Fuping Blocks, and between the Fuping and Eastern Blocks occur after closure of the Luliang and Taihang oceans, respectively, at around $1880 \mathrm{Ma}$ ( [Trap et al., 2007] and [Trap et al., 2009a] ).

At ca. 1900-1880 Ma, top-to-the-SE ductile and synmetamorphic shearing deformed the bimodal volcanic-sedimentary series and the calc-alkaline plutons corresponding to the Orthogneiss-and-Volcanite Unit. The continental crust of the Fuping Block was sliced to the SE by intracontinental thrusts such as the Longquanguan Shear Zone. This event corresponds to the D1 deformation related to nappe-stacking and crustal thickening during orogenic wedge building ( [Faure et al., 2007] , [Trap et al., 2007] , [Trap et al., 2008] and [Trap et al., 2009b] ). The achievement of crustal thickening might have occurred around $1880 \pm 10 \mathrm{Ma}$ that dates the peak of the prograde M1 metamorphism within the amphibolite facies OVU (Trap et al., 2007, this study). The ${ }^{40} \mathrm{Ar} /{ }^{39} \mathrm{Ar}$ age of $1873 \pm 12 \mathrm{Ma}$ obtained in this study is attributed to the end of D1/M1 event.

During ongoing compression of the thickened orogenic root, the onset of partial-melting of deep seated rocks at peak metamorphism is responsible for a first strength drop that enhanced an eastward lateral flow of the orogenic root (Trap et al., 2011). Radiometric ages show that the deep crust was partially molten over a 50 Ma lasting period (Trap et al., 2011 and reference therein) as bracketed by the $1872 \pm 17$ and $1819 \pm 13 \mathrm{U}-\mathrm{Pb}$ ages recorded for the migmatitic leucosomes ( [Kröner et al., 2005a] and [Wang et al., 2010b] ). The amphibole ${ }^{40} \mathrm{Ar} /{ }^{39} \mathrm{Ar}$ age of $1855 \pm 10 \mathrm{Ma}$ obtained on the partially molten Yixingzhai gneiss corresponds also to this widespread migmatization. Partial melting is coeval with a D2 deformation that developed during lateral flow and exhumation of the HPB (Trap et al., 2011). Synchronously, the D2 deformation was responsible for the folding of the middle and upper parts of the orogenic wedge that consequently acquired a fan-type geometry ( [Trap et al., 2009b] , [Zhang et al., 2007] and [Zhang et al., 2009] ).

The erosion of the thickened crust led to the deposition of the Hutuo Supergroup sediments as syn-collisional molasse basins. Considering structural relationships with underlying metamorphic rocks, Faure et al. (2007) and Trap et al. (2007) considered that the Hutuo Supergroup deposited around 1850 Ma during D2. Within the Hutuo Supergroup sedimentary rocks, numerous detrital zircons recorded ages around $2.5 \mathrm{Ga}$ and 2.2-2.0 $\mathrm{Ga}$ ( [Du et al., 2010] , [Liu et al., 2011a] , [Liu et al., 2011b] and [Wan et al., 2010] ). However, the recent discovery of $\sim 1.88 \mathrm{Ga}$ detrital zircons in the Upper Dongye and Guojiazhai Subgroups of the Hutuo Supergroup indicates that they deposited after $\sim 1.88 \mathrm{Ga}$ (Liu et al., 2010). In the Fuping Massif, a lower time limit is given by the Pingshan fault that reworked terrigeneous sedimentary rocks belonging to the Hutuo Supergroup. This fault developed during the D3 late-orogenic extensional deformation. In the Luliang Massif, the youngest ages of the Hutuo Supergroup are around 1.87-1.81 Ga (_Liu et al., 2011a] and [Liu et al., 2011b] ). Therefore, we can consider that the Hutuo Supergroup deposited between 1880 and 1810 Ma after the main tectono-metamorphic events.

The late deformation event, named D4, is defined by strike-slip shear zones among which the Zhujiafang shear Zone is the most prominent. Our two biotite ${ }^{40} \mathrm{Ar} /{ }^{39} \mathrm{Ar}$ ages at $1812 \pm 13 \mathrm{Ma}$ and $1810 \pm 13$ Ma obtained on the ZSZ mylonites suggest a strike slip regime around 1810 Ma. This is in agreement with model 1 (Zhang et al., 2007) that proposes the development of the ZSZ in the late collisional stage. Finally, the $\sim 1800 \mathrm{Ma}{ }^{40} \mathrm{Ar} /{ }^{39} \mathrm{Ar}$ (this study) and $\mathrm{U}-\mathrm{Pb}$ 
ages from undeformed granitoids (e.g. Yu et al., 2004) mark the post-orogenic unroofing and the end of the Trans-North China Orogeny.

\section{Conclusion}

The Paleoproterozoic geodynamic evolution of the TNCO is quite similar to that of the modern-type collisional orogens. In contrast to many Precambrian Orogens, the important tectonic features of the TNCO are (i) clear suture zones with ophiolites, turbidites, and subduction related material; (ii) juxtaposition of tectono-metamorphic units with contrasting metamorphic grades; (iii) development of lithospheric-scale thrusts responsible for nappe staking and crustal thickening; (iii) syn-orogenic sedimentary basins related to erosion of the orogenic wedge; (iv) syn- and post-thickening extension with crustal-scale detachments and (v) tectonically driven exhumation of HP/UHP metamorphic rocks. As in many modern collisional belts, the crustal partial-melting can be seen as a syn- to late-orogenic response to the thermal disturbance due to crustal thickening. Like any model, the above proposed one is not definitive, and requires further improvements. Forthcoming structural, petrological and geochronological studies coupling forward thermodynamic modelling and in situ dating are needed to build-up precise $\mathrm{P}-\mathrm{T}-\mathrm{t}-\mathrm{D}$ paths that are crucial for understanding the tectonic evolution of the TNCO. In particular, the tectonic significance of HT and UHT metamorphism within the NCC is not clearly settled yet. In the future, precise $\mathrm{P}-\mathrm{T}-\mathrm{t}-\mathrm{D}$ studies will help us to clearly define the metamorphic characters within the NCC.

\section{Acknowledgments}

This research was financially supported by a National Science Foundation of China grant no. 40472116. ${ }^{40} \mathrm{Ar}-{ }^{39} \mathrm{Ar}$ analyses were performed at the University of Montpellier II, France.

We thank O. Rouer who performed X-ray composition maps, N. Carry who helped in figure drawing. Prof. M. Santosh and an anonymous reviewer are acknowledged for their very constructive comments helping to significantly improve the manuscript. Dr. Guochun Zhao is thanked for editorial handling and for the valuable help with correction of the manuscript.

\section{References}

Bai, 1993 J. Bai, The Precambrian Geology and $\mathrm{Pb}-\mathrm{Zn}$ Mineralization in the Northern Margin of North China Platform, Geological Publishing House, Beijing (1993).

Berman, 1988 R.G. Berman, Internally consistent thermodynamic data for minerals in the system $\mathrm{N}_{2} \mathrm{O}-\mathrm{K}_{2} \mathrm{O}-\mathrm{CaO}-\mathrm{MgO}-\mathrm{FeO}-\mathrm{Fe}_{2} \mathrm{O}_{3}-\mathrm{Al}_{2} \mathrm{O}_{3}-\mathrm{SiO}_{2}-\mathrm{TiO}_{2}-\mathrm{H}_{2} \mathrm{O}-\mathrm{CO}_{2}$. J. Petrol., 29 (1988), pp. 445-522.

Berman, 1991 R.G. Berman, Thermobarometry using multi-equilibrium calculations: a new technique, with petrological applications. Can. Miner., 29 (1991), pp. 833-855.

Bai and Dai, 1998 J. Bai and F.Y. Dai, Archean crust of China, X.Y. Ma, J. Bai, Editors, Precambrian Crust Evolution of China, Beijing, Springer/Geological Publishing House (1998), pp. 15-86.

Cagnard et al., 2006 F. Cagnard, J.P. Brun and D. Gapais, Modes of thickening of analogue weak lithospheres. Tectonophysics, 421 (2006), pp. 145-160. 
Cagnard et al., 2007 F. Cagnard, D. Gapais and P. Barbey, Collision tectonics involving juvenile crust: the example of the southern Finnish Svecofennides. Precambrian Res., 154 (2007), pp. 125-141.

Cagnard et al., 2011 F. Cagnard, P. Barbey and D. Gapais, Transition between Archaean-type and modern-type tectonics: insights from the Finnish Lapland Granulite Belt. Precambrian Res., 187 (2011), pp. 127-142.

Chardon et al., 2009 D. Chardon, D. Gapais and F. Cagnard, Flow of ultra-hot orogens: a view from the Precambrian, clues for the Phanerozoic. Tectonophysics, 477 (2009), pp. 105118.

Cheng et al., 2001 Y.Q. Cheng, Y.S. Wan, J.F. Gao and R. Ma, Petrographic characteristics of three anatectically transformed metamorphic rock types of the Fuping Group-Complex of the Xiaojue Region, Pingshan, Hebei, .Geol. Rev., 47 (2001), pp. 1-8 (in Chinese with English abstract).

Choukroune et al., 1993 P. Choukroune, B. Auvray, B.M. Jahn, T. Chen, Y. Geng and D. Liu, Coupe structurale de la croûte Archéenne en Hebei (Craton sino-coréen, Chine du nord). C. $R$. Acad. Sci. Paris, 316 (1993), pp. 669-675.

Collins et al., 2004 A.S. Collins, S.M. Reddy, C. Buchan and A. Mruma, Temporal constraints on Palaeoproterozoic eclogite formation and exhumation (Usagaran Orogen, Tanzania). Earth Planet. Sci. Lett., 224 (2004), pp. 175-192.

Condie et al., 1992 K.C. Condie, M.D. Boryta and J. Liu, The origin of khondalites: geochemical evidence from the Archean to early Proterozoic granulite belt in the North China Craton. Precambrian Res., 59 (1992), pp. 207-223.

Cruden et al., 2006 A.R. Cruden, M.H. Nasseri and R. Pysklywec, Surface topography and internal strain variation in wide hot orogens from three-dimensional analogue and twodimensional numerical vice models, S.J.H. Buiter, G. Schreurs, Editors, Analogue and Numerical Modelling of Crustal-scale Processes. Geol. Soc. London Spec. Publ. 253 (2006), pp. 79-104.

Dahl, 1996 P. Dahl, The effects of composition on retentivity of argon and oxygen in hornblende and related amphiboles: a field-tested empirical model. Geochem. Cosmochim. Acta, 60 (1996), pp. 3687-3700.

Dalrymple, 1989 G.B. Dalrymple, The GLM continuous laser system for ${ }^{40} \mathrm{Ar}-{ }^{39} \mathrm{Ar}$ dating: description and performance characteristics, W.C. Shanks, R. Criss, Editors, New Frontiers in Stable Isotope Res, USGS Bull. 1890 (1989), pp. 89-96.

Di Vincenzo et al., 2003 G. Di Vincenzo, C. Viti and S. Rocchi, The effect of chlorite interlayeringon ${ }^{40} \mathrm{Ar}-{ }^{39} \mathrm{Ar}$ biotite dating: an ${ }^{40} \mathrm{Ar}-{ }^{39} \mathrm{Ar}$ laser-probe and TEM investigations of variably chloritised biotites. Contrib. Mineral. Petrol., 145 (2003), pp. 643-658.

Dirks et al., 1997 P.H.G.M. Dirks, J.S. Zhang and W.C. Passchier, Exhumation of highpressure granulites and the role of lower crustal advection in the North China Craton near Datong. J. Struct. Geol., 19 (1997), pp. 1343-1358. 
Du et al., 2010 L.L. Du, C.H. Yang, J.H. Guo, W. Wang, L.D. Ren, Y.S. Wan and Y.S. Geng, The age of the base of the Paleoproterozoic Hutuo Group in the Wutai Mountains area, North China Craton: SHRIMP zircon U-Pb dating of basaltic andesite. Chin. Sci. Bull., 55 (2010), pp. 1782-1789.

Duguet et al., 2007 M. Duguet, N. Le Breton and M. Faure, P-T paths reconstruction of a collisional event: the example of the Thiviers-Payzac Unit in the Variscan French Massif Central. Lithos, 98 (2007), pp. 210-232.

Faure et al., 2004 M. Faure, W. Lin, P. Monié and O. Bruguier, Palaeoproterozoic arc magmatism and collision in Liaodong Peninsula (north-east China). Terra Nova, 16 (2004), pp. $75-80$

Faure et al., 2007 M. Faure, P. Trap, W. Lin, P. Monié and O. Bruguier, Polyorogenic evolution of the Paleoproterozoic Trans-North China Belt, new insights from the Lüliangshan-Hengshan-Wutaishan and Fuping massifs. Episodes, 30 (2007), pp. 1-12.

Fitzsimons et al., 2005 I.C.W. Fitzsimons, P.D. Kinny, S. Wetherley and D.A. Hollingsworth, Bulk chemical control on metamorphic monazite growth in pelitic schists and implications for U-Pb age data. J. Metamorph. Geol., 23 (2005), pp. 261-277.

Gapais et al., 2009 D. Gapais, F. Cagnard, F. Gueydan, P. Barbey and M. Ballèvre, Mountain building and exhumation processes through time: inferences from nature and models. Terra Nova, 21 (2009), pp. 188-194.

Geng et al., 2000 Y.S. Geng, Y.S. Wan, Q.H. Shen, H.M. Li and R.X. Zhang, Chronological framework of the early Precambrian important events in the Lüliang area, Shanxi Province, . Acta Geol. Sin., 74 (2000), pp. 216-223 (in Chinese with English abstract).

Geng et al., 2004 Y.S. Geng, C.H. Yang, B. Song and Y.S. Wang, Post-orogenic granites with an age of $1800 \mathrm{Ma}$ in Lüliang area. North China Craton: constraints from isotopic geochronology and geochemistry, . Geol. J. China Univ., 10 (2004), pp. 477-487 (in Chinese with English abstract).

Guan et al., 2002 H. Guan, M. Sun, S.A. Wilde, X.H. Zhou and M.G. Zhai, SHRIMP U-Pb zircon geochronology of the Fuping Complex: implications for formation and assembly of the North China Craton. Precambrian Res., 113 (2002), pp. 1-18

Guo et al., 1993 J.H. Guo, M.G. Zhai and Y.G. Zhang, Early Precambrian Manjinggou highpressure granulites melange belt on the southern edge of the Huai'an Complex, North China Craton: geological features, petrology and isotopic geochronology. Acta Petrol.

Sin., 9 (1993), pp. 329-341.

Guo et al., 2002 J.H. Guo, P.J. O'Brien and M.G. Zhai, High-pressure granulites in the Sanggan area, North China Craton: metamorphic evolution, $\mathrm{P}-\mathrm{T}$ paths and geotectonic significance. J. Metamorph. Geol., 20 (2002), pp. 741-756.

Guo et al., 2005 Guo, J.H., Sun, M., Zhai, M.G., 2005. Sm-Nd and SHRIMP U-Pb zircon geochronology of high-pressure granulites in the Sanggan area, North China Craton: timing of 
Paleoproterozoic continental collision. In: Wilde, S.A., Zhao, G.C. (Eds.), Late Archean to Paleoproterozoic Evolution of the North China Craton. J. Asian Earth Sci. 24, 529-542.

Guo et al., 2006 Guo, J.H., Chen,Y., Liu, F. 2006. Ultra-high temperature (UHT) metamorphism of sapphirine-bearing granulite with $\sim 1.8 \mathrm{Ga}$ age in Daqingshan, Inner Mongolia. In: Abstract Volume of 2006 National Symposium of Petrology and Geodynamics, Nanjing University, Nanjing, 215-218pp..

Hao et al., 1995 J. Hao, K.Y. Wang and S.P. Zhou, Discussion on stratigraphic and tectonic features of Longquanguan Group in the south west piedmont of Wutai Mountain and relevant problems, . Sci. Geol. Sin., 30 (1995), pp. 183-189 (in Chinese with English abstract).

Harrison et al., 1985 T.M. Harrison, I. Duncan and I. McDougall, Diffusion of ${ }^{40} \mathrm{Ar}$ in biotite. Geochem. Cosmochim. Acta, 49 (1985), pp. 2461-2468.

HBGMR, 1989 HBGMR (Henan Bureau of Geology and Mineral Resources), Regional Geology of Shanxi Province, Geological Publishing House, Beijing (1989), 742pp..

He and Ye, 1998 G.P. He and H.W. Ye, Two type of early Proterozoic metamorphism in the eastern Liaoning to southern Jilin and their tectonic implication. Acta Petrol. Sin., 14 (1998), pp. 152-162.

Holland and Powell, 1998 T.B.J. Holland and R. Powell, An internally-consistent thermodynamic data set for phases of petrological interest. J. Metamorph. Geol., 16 (1998), pp. 309-343.

Hollister, 1966 L.S. Hollister, Garnet zoning: an interpretation based upon the Rayleigh fractionation model. Science, 154 (1966), pp. 1647-1651.

Jiao et al., 2011 S.H. Jiao, J.H. Guo, Q. Mao and R.F. Zhao, Application of Zr-in-rutile thermometry: a case study from ultrahigh-temperature granulites of the Khondalite belt, North China Craton. Contrib. Mineral. Petrol., 162 (2011), pp. 379-393.

Jiao and Guo, 2010 S.H. Jiao and J.H. Guo, Application of the two-feldspar geothermometer to ultrahigh-temperature (UHT) rocks in the Khondalite belt, North China Craton and its implications. Am. Mineral., 96 (2010), pp. 250-260.

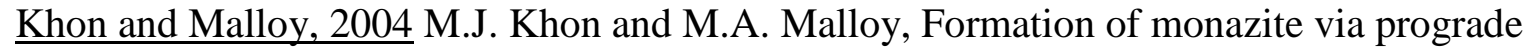
metamorphic reactions among common silicates: implications for age determinations.

Geochem. Cosmochim. Acta, 68 (2004), pp. 101-113.

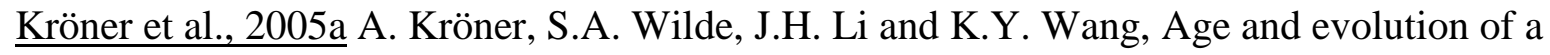
late Archean to Paleoproterozoic upper to lower crustal section in the Wutaishan/Hengshan/Fuping terrain of northern China. J. Asian Earth Sci., 24 (2005), pp. 577-595.

Kröner et al., 2005b A. Kröner, S.A. Wilde, P.J. O’Brien, J.H. Li, C.W. Passchier, N.P. Walte and D.Y. Liu, Field relationships, geochemistry, zircon ages and evolution of a late Archaean to Palaeoproterozoic lower crustal section in the Hengshan Terrain of northern China. Acta Geol. Sin., 79 (2005), pp. 605-632. 


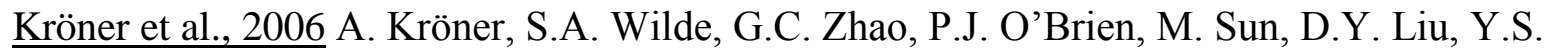
Wan, S.W. Liu and J.H. Guo, Zircon geochronology and metamorphic evolution of mafic dykes in the Hengshan Complex of northern China: evidence for late Palaeoproterozoic extension and subsequent high-pressure metamorphism in the North China Craton. Precambrian Res., 146 (2006), pp. 45-67.

Kusky, 2011 T.M. Kusky, Geophysical and geological tests of tectonic models of the North China Craton. Gondwana Res., 20 (2011), pp. 26-35.

Kusky and Li, 2003 T.M. Kusky and J.H. Li, Paleoproterozoic tectonic evolution of the North China Craton. J. Asian Earth Sci., 22 (2003), pp. 23-40.

Kusky et al., 2007 T.M. Kusky, J.H. Li and M. Santosh, The Paleoproterozoic North Hebei Orogen: North China Craton's collisional suture with the Columbia supercontinent. Gondwana Res., 12 (2007), pp. 4-28.

Kusky and Santosh, 2009 T.M. Kusky and M. Santosh, The Columbia connection in North China, S.M. Reddy, R. Mazumder, D. Evans, A.S. Collins, Editors, Paleoproterozoic Supercontinents and Global Evolution. Geol. Soc. London Spec. Publ. 323 (2009), pp. 49-71.

Li et al., 1998 J.H. Li, M.G. Zhai, Y.G. Li and Y.G. Zhan, Discovery of late Archean highpressure granulites in Luanping-Chengde area, Northern Hebei Province: tectonic implications. Acta Petrol. Sin., 14 (1998), pp. 34-41.

Li et al., 2000a J.H. Li, X.L. Qian, X.N. Huang and S.W. Liu, The tectonic framework of the basement of North China Craton and its implication for the early Precambrian cratonization. Acta Petrol. Sin., 16 (2000), pp. 1-10.

Li et al., 2000b J.H. Li, A. Kröner, X.L. Qian and P. O'Brien, The tectonic evolution of an early Precambrian high-pressure granulite belt in the North China Craton. Acta Geol.

Sin., 74 (2000), pp. 246-256.

Li et al., 2004 J.H. Li, S.L. Niu and Z. Chen, Discovery of the deep thrusting structure in the Taihangshan area and its tectonic implications. Adv. Nat. Sci., 14 (2004), pp. 1118-1127.

Li and Kusky, 2007 J.H. Li and T.M. Kusky, A late Archean foreland fold and thrust belt in the North China Craton: implications for early collisional tectonics. Gondwana Res., 12 (2007), pp. 47-66.

Li and Zhao, 2007 S.Z. Li and G.C. Zhao, SHRIMP U-Pb zircon geochronology of the Liaoji granitoids: constraints on the evolution of the Paleoproterozoic Jiao-Liao-Ji Belt in the Eastern Block of the North China Craton. Precambrian Res., 158 (2007), pp. 1-16.

Li et al., 2005 S.Z. Li, G.C. Zhao, M. Sun, Z.Z. Han, Y. Luo, D.F. Hao and X.P. Xia, Deformation history of the Paleoproterozoic Liaohe assemblage in the eastern block of the North China Craton. J. Asian Earth Sci., 24 (2005), pp. 659-674.

Li et al., 2006 S.Z. Li, G.C. Zhao, M. Sun, Z.Z. Han, G.T. Zhao and D.F. Hao, Are the South and North Liaohe Groups of the North China Craton different exotic terranes? Nd isotope constraints. Gondwana Res., 9 (2006), pp. 198-208. 
Li et al., 2010 S.Z. Li, G.C. Zhao, S.A. Wilde, J. Zhang, M. Sun, G.W. Zhang and L.M. Dai, Deformation history of the Hengshan-Wutai-Fuping Complexes: implications for the evolution of the Trans-North China Orogen. Gondwana Res., 18 (2010), pp. 611-631.

$\underline{\text { Liu, } 1996}$ S.W. Liu, Study on the P-T path of granulites in Fuping area, Hebei Province, . Geol. J. Univ., 2 (1996), pp. 75-84 (in Chinese with English abstract).

Liu and Liang, 1997 S.W. Liu and H.H. Liang, Metamorphism of Al-rich gneisses from the Fuping Complex, Tahang Mountain, China. Acta Petrol. Sin., 13 (1997), pp. 303-312.

Liu et al., 1993 X.S. Liu, W. Jin, S.X. Li and X.C. Xu, Two types of Precambrian high-grade metamorphism, Inner Mongolia, China. J. Metamorph. Geol., 11 (1993), pp. 499-510.

Liu et al., 2002 S.W. Liu, J.H. Li, Y.M. Pan, J. Zhang and Q.G. Li, An Archean continental block in the Taihangshan and Hengshan regions: constraints from geochronology and geochemistry. Prog. Nat. Sci., 12 (2002), pp. 568-576.

Liu et al., 2004 S.W. Liu, P.M. Pan, Q.L. Xie, J. Zhang and Q.G. Li, Archean geodynamics in the Central Zone, North China Craton: constraints from geochemistry of two contrasting series of granitoids in the Fuping and Wutai Complexes. Precambrian Res., 130 (2004), pp. 229-249.

Liu et al., 2010 S.J. Liu, J.H. Li and M. Santosh, First application of the revised Ti-in-zircon geothermometer to Paleoproterozoic ultrahigh-temperature granulites of Tuguiwula, Inner Mongolia, North China Craton. Contrib. Mineral. Petrol., 159 (2010), pp. 225-235.

Liu et al., 2011a C.H. Liu, G.C. Zhao, M. Sun, F.Y. Wu, J.H. Yang, C.Q. Yin and W.H. Leung, $\mathrm{U}-\mathrm{Pb}$ and $\mathrm{Hf}$ isotopic study of detrital zircons from the Yejishan Group of the Lüliang Complex: constraints on the timing of collision between the Eastern and Western Blocks, North China Craton. Sediment. Geol., 236 (2011), pp. 129-140.

Liu et al., 2011b C.H. Liu, G.C. Zhao, M. Sun, F.Y. Wu, J. Zhang, Y.H. He, C.Q. Yin, F.Y. $\mathrm{Wu}$ and J.H. Yang, U-Pb and Hf isotopic study of detrital zircons from the Hutuo group in the Trans-North China Orogen and tectonic implications. Gondwana Res., 20 (2011), pp. $106-121$.

Lu et al., 1992 L.Z. Lu, S.Q. Jin, X.T. Xu and F.L. Liu, Petrogenesis and Mineralization of Khondalite Series in Southeastern Inner Mongolia, Jilin Science \& Technology Press, Changchun (1992).

Lu et al., 1995 L.Z. Lu, X.C. Xu and F.L. Liu, The Precambrian Khondalite Series in Northern China, Changchun Publishing House, Changchun (1995), 1-99pp..

Luo et al., 2004 Y. Luo, M. Sun, G.C. Zhao, S.Z. Li, P. Xu, K. Ye and X.P. Xia, LA-ICP-MS $\mathrm{U}-\mathrm{Pb}$ zircon ages of the Liaohe Group in the Eastern Block of the North China Craton: constraints on the evolution of the Jiao-Liao-Ji Belt. Precambrian Res., 134 (2004), pp. 349371.

Luo et al., 2008 Y. Luo, M. Sun, G.C. Zhao, J.C. Ayers, S.Z. Li, X.P. Xia and J.H. Zhang, A comparison of $\mathrm{U}-\mathrm{Pb}$ and $\mathrm{Hf}$ isotopic compositions of detrital zircons from the North and 
South Liaohe Group: constraints on the evolution of the Jiao-Liao-Ji Belt, North China Craton. Precambrian Res., 163 (2008), pp. 279-306.

Monié et al., 1994 P. Monié, R.L. Torres-Roldan and A. Garcia-Casco, Cooling and exhumation of the western Betic Cordilleras, ${ }^{40} \mathrm{Ar} /{ }^{40} \mathrm{Ar}$ thermochronological constraints on a collapsed terrane. Tectonophysics, 238 (1994), pp. 353-379.

Monié et al., 1997 P. Monié, R. Caby and M.H. Arthaud, The neoproterozoic Brasiliano orogeny in northeast Brazil: ${ }^{40} \mathrm{Ar} /{ }^{39} \mathrm{Ar}$ and petro-structural data from Ceara. Precambrian Res., 81 (1997), pp. 241-264.

Niu et al., 1994 S.Y. Niu, C.S. Xu and L.J. Guo, The characteristics of metamorphic core complex in Taihang Mountains and its genesis. J. Hebei Col. Geol., 17 (1994), pp. 43-52.

O'Brien et al., 2005 P.J. O'Brien, N. Walte and J.H. Li, The petrology of two distinct granulite types in the Hengshan Mts, China, and tectonic implications. J. Asian Earth Sci., 24 (2005), pp. 615-627.

Pei et al., 2001 L.T. Pei, M. Yang, G.X. Ma, T.P. Hao, Z.H. Han and J.L. Bin, The geological character of the Longquanguan ductile shear zone, . Beijing Geol., 13 (2001), pp. 1-11 (in Chinese with English abstract).

Peng et al., 2005 P. Peng, M.G. Zhai, H.F. Zhang and J.H. Guo, Geochronological constraints on the palaeoproterozoic evolution of the North China Craton: SHRIMP zircon ages of different types of Mafic dikes. Int. Geol. Rev., 47 (2005), pp. 492-508.

Polat et al., 2005 A. Polat, T. Kusky, J.H. Li, B. Fryer, R. Kerrich and K. Patrick, Geochemistry of Neoarchean (ca. 2.55-2.50 Ga) volcanic and ophiolitic rocks in the Wutaishan greenstone belt, central orogenic belt, North China Craton: implications for geodynamic setting and continental growth. Bull. Geol. Soc. Am., 117 (2005), pp. 13871399.

Polat et al., 2006 A. Polat, C. Hersberg, C. Münker, R. Rodgers, T. Kusky, J.H. Li, B. Fryer and J. Delaney, Geochemical and petrological evidence for a suprasubduction zone origin of Neoarchean (ca. $2.5 \mathrm{Ga}$ ) peridotites, central orogenic belt, North China Craton. Bull. Geol. Soc. Am., 118 (2006), pp. 771-784.

Powell and Holland, 1988 R. Powell and T.J.B. Holland, An internally consistent thermodynamic dataset with uncertainties and correlations: 3: application, methods, worked examples and a computer program. J. Metamorph. Geol., 6 (1988), pp. 173-204.

Powell and Holland, 1994 R. Powell and T.J.B. Holland, Optimal geothermometry and geobarometry. Am. Mineral., 79 (1994), pp. 120-133.

Rogers and Santosh, 2002 J.J.W. Rogers and M. Santosh, Configuration of Columbia, a Mesoproterozoic Supercontinent. Gondwana Res., 5 (2002), pp. 5-22.

Rogers and Santosh, 2009 J.J.W. Rogers and M. Santosh, Tectonics and surface effects of the supercontinent Columbia. Gondwana Res., 15 (2009), pp. 373-380. 
Samson and Alexander, 1987 S.D. Samson and C.J.R. Alexander, New developments and applications in isotope geoscience, International Conference on Geochronology, Cosmochronology and Isotope Geology (ICOG IV), vol. 6Cambridge (1987) pp. 66, 27-34.

Santosh, 2010 M. Santosh, Assembling North China Craton within the Columbia supercontinent: the role of double-sided subduction. Precambrian Res., 178 (2010), pp. 149167.

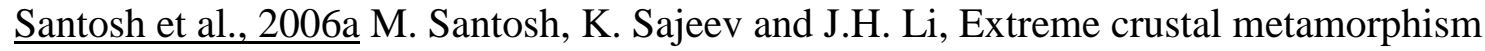
during Columbia supercontinent assembly: evidence from North China Craton. Gondwana Res., 10 (2006), pp. 256-266.

Santosh et al., 2006b M. Santosh, A.S. Collins, I. Tamashiro, S. Koshimoto, Y. Tsutsumi and K. Yokoyama, The timing of ultrahigh-temperature metamorphism in Southern India: U-Th$\mathrm{Pb}$ electron microprobe ages from zircon and monazite in sapphirine-bearing granulites. Gondwana Res., 10 (2006), pp. 128-155.

Santosh et al., 2007a M. Santosh, T. Tsunogae, J.H. Li and S.J. Liu, Discovery of sapphirinebearing $\mathrm{Mg}-\mathrm{Al}$ granulites in the North China Craton: implication for Paleoproterozoic ultrahigh-temperature metamorphism. Gondwana Res., 159 (2007), pp. 178-196.

Santosh et al., 2007b M. Santosh, S.A. Wilde and J.H. Li, Timing of Paleoproterozoic ultrahigh-temperature metamorphism in the North China Craton: evidence from SHRIMP UPb zircon geochronology. Precambrian Res., 159 (2007), pp. 178-196.

$\underline{\text { Santosh et al., } 2009}$ M. Santosh, K. Sajeev, J.H. Li, S.J. Liu and T. Itaya, Counterclockwise exhumation of a hot orogen: the Paleoproterozoic ultrahigh-temperature granulites in the North China Craton. Lithos, 110 (2009), pp. 140-152.

SBGMR, 1989 SBGMR (Shanxi Bureau of Geology and Mineral Resources), Regional Geology of Shanxi Province, Geological Publishing House, Beijing (1989), 780pp..

Spear et al., 1990 F.S. Spear, M.J. Kohn, F. Florence and T. Menard, A model for garnet and plagioclase growth in pelitic schists: implications for thermobarometry and P-T path determinations. J. Metamorph. Geol., 8 (1990), pp. 683-696.

Spear and Pyle, 2002 F.S. Spear and J.M. Pyle, Apaptite, monazite, and xenotime in metamorphic rocks, Reviews in Mineralogy and Geochemistry, Mineral. Soc. Am., vol. 48 ,in: M.J. Khon, J. Rakovan, J.M. Hugues, Editors, Phosphates: Geochemical, Geobiological and Materials Importance (2002), pp. 293-335.

Sun et al., 1993 D.Y. Sun, Z.H. Liu and C.Q. Zheng, Metamorphism and Tectonic Evolution of Early Precambrian Rocks in Fushun Area, the Northern Liaoning Province, Seismological Press, Beijing (1993), pp. 90-120 (in Chinese).

Sun et al., 2004 Z.L. Sun, J.R. Li, C.R. Liu, Y.S. Zhang, Y.H. Yang and W.S. Yan, Another view on the Longquanguan ductile shear zone, . Geol. Surv. Res., 27 (2004), pp. 92-100 (in Chinese with English abstract). 
Tian, 1991 Y.Q. Tian, Geology and Gold Mineralization of Wutai-Hengshan Greenstone Belt, Shanxi Science and Technology Press, Taiyuan (1991).

Tinkham et al., 2001 D.K. Tinkham, C.A. Zuluaga and H.H. Stowell, Metapelite phase equilibria modelling in MnNCKFMASH: the effect of variable $\mathrm{Al}_{2} \mathrm{O}_{3}$ and $\mathrm{MgO} /(\mathrm{MgO}+\mathrm{FeO})$ on mineral stability. Geol. Mater. Res., 3 (2001), pp. 1-42.

Trap et al., 2007 P. Trap, M. Faure, W. Lin and P. Monié, Late Paleoproterozoic (1900-1800 Ma) nappe-stacking and polyphase deformation in the Hengshan-Wutaishan area: implications for the understanding of the Trans-North-China Belt, North China Craton. Precambrian Res., 156 (2007), pp. 85-106.

Trap et al., 2008 P. Trap, M. Faure, W. Lin, O. Bruguier and P. Monié, Contrasted tectonic styles for the Paleoproterozoic evolution of the North China Craton. Evidence for a $\sim 2.1 \mathrm{Ga}$ thermal and tectonic event in the Fuping Massif. J. Struct. Geol., 30 (2008), pp. 1109-1125.

Trap et al., 2009a P. Trap, M. Faure, W. Lin, P. Monié, S. Meffre and J. Melleton, The Zanhuang Massif, the second and eastern suture zone of the Paleoproterozoic Trans-North China Orogen. Precambrian Res., 172 (2009), pp. 80-98.

Trap et al., 2009b P. Trap, M. Faure, W. Lin, P. Monié and S. Meffre, The Lüliang Massif: a key area for the understanding of the Palaeoproterozoic, D. Evans, S. Reddy, A. Collins, Editors, Palaeoproterozoic Supercontinents and Global Evolution. Geol. Soc. London Spec. Publ. 323 (2009), pp. 99-125.

Trap et al., 2011 P. Trap, M. Faure, W. Lin, R. Augier and A. Fouassier, Syn-collisional channel flow and exhumation of Paleoproterozoic high-pressure rocks in the Trans-North China Orogen: the critical role of partial-melting and orogenic bending. Gondwana Res., 20 (2011), pp. 498-515.

Tsunogae et al., 2011 T. Tsunogae, S.J. Liu, M. Santosh, H. Shimizu and J.H. Li, Ultrahightemperature metamorphism in Daqingshan, Inner Mongolia Suture Zone, North China Craton. Gondwana Res., 20 (2011), pp. 36-47.

Turner, 1968 G. Turner, The distribution of potassium and argon in chondrites, L.H. Ahrens, Editor, Origin and Distribution of the Elements, Pergamon, Oxford (1968), pp. 387-398.

Vidal et al., 2009 M. Vidal, C. Gumiaux, F. Cagnard, A. Pouclet, G. Ouattara and M. Pichon, Evolution of a Paleoproterozoic «weak type» orogeny in the West African Craton (Ivory Coast). Tectonophysics, 477 3-4 (2009), pp. 145-159.

Wan et al., 2000 Y.S. Wan, Y.S. Geng, Q.H. Shen and R.X. Zhang, Khondalite seriesgeochronology and geochemistry of the Jiehekou Group in the Lüliang area, Shanxi Province. Acta Petrol. Sin., 16 (2000), pp. 49-58.

Wan et al., 2006 Y.S. Wan, S.A. Wilde, D.Y. Liu, C.X. Yang, B. Song and X.Y. Yin, Further evidence for $\sim 1.85 \mathrm{Ga}$ metamorphism in the Central Zone of the North China Craton:

SHRIMP U-Pb dating of zircon from metamorphic rocks in the Lushan area, Henan Province. Gondwana Res., 9 (2006), pp. 189-197. 
Wan et al., 2010 Y.S. Wan, P.S. Miao, D.Y. Liu, C.H. Yang, W. Wang, H.C. Wang, Z.J. Wang, C.Y. Dong, L.L. Du and H.Y. Zhou, Formation ages and source regions of the Palaeoproterozoic Gaofan, Hutuo and Dongjiao groups in the Wutai and Dongjiao areas of the North China Craton from the SHRIMP U-Pb dating of detrital zircons: resolution of debates over their stratigraphic relationships. Chin. Sci. Bull., 55 (2010), pp. 1278-1284.

Wang, 2009 Z.H. Wang, Tectonic evolution of the Hengshan-Wutai-Fuping Complexes and its implication for the Trans-North China Orogen. Precambrian Res., 131 (2009), pp. 323343.

Wang, 2010 Z.H. Wang, Reply to the comment by Zhao et al. on: "Tectonic evolution of the Henghsan-Wutai-Fuping Complexes and its implication for the Trans-North China Orogen" [Precambrian Res. 170 (2009) 73-87]. Precambrian Res., 176 (2010), pp. 99-104

Wang et al., 1997 K.Y. Wang, J. Hao, P. Cawood and S.A. Wilde, High-pressure metamorphism in kyanite-bearing schists from the original Jingangku Formation of the Wutaishan Proceeding of the 30th IGC: Precambrian Geol. Metamorph. Petrol., vol. 17 (1997), pp. 213-220.

Wang et al., 2004 Z. Wang, S.A. Wilde, K. Wang and L. Yu, A MORB-arc basalt-adakite association in the $2.5 \mathrm{Ga}$ Wutai greenstone belt: late Archean magmatism and crustal growth in the North China Craton. Precambrian Res., 131 (2004), pp. 323-343.

Wang et al., 2010a Z.H. Wang, S.A. Wilde and J.L. Wan, Tectonic setting and significance of 2.3-2.1 Ga magmatic events in the Trans-North China Orogen: new constraints from the Yanmenguan mafic-ultramafic intrusion in the Hengshan-Wutai-Fuping Area. Precambrian Res., 178 (2010), pp. 27-42.

Wang et al., 2010b J. Wang, Y.B. Wu, S. Gao, M. Peng, X.C. Liu, L.S. Zhao, L. Zhou, Z.C. $\mathrm{Hu}, \mathrm{H} . J$. Gong and Y.S. Liu, Zircon U-Pb and trace element data from rocks of the Huai' an Complex: new insights into the late Paleoproterozoic collision between the Eastern and Western Blocks of the North China Craton. Precambrian Res., 178 (2010), pp. 59-71.

Wilde et al., 1998 S.A. Wilde, P.A. Cawood, K.Y. Wang and A. Nemchin, SHRIMP U-Pb zircon dating of granites and gneisses in the Taihangshan-Wutaishan area: implications for the timing of crustal growth in the North China Craton. Chin. Sci. Bull., 43 (1998), pp. 144145.

Wilde et al., 2002 S.A. Wilde, G.C. Zhao and M. Sun, Development of the North China Craton during the late Archean and its final amalgamation at $1.8 \mathrm{Ga}$; some speculations on its position within a global Paleoprterozoic Supercontinent. Gondwana Res., 5 (2002), pp. 8594.

Wilde et al., 2004a S.A. Wilde, P.A. Cawood, K.Y. Wang, A. Nemchin and G.C. Zhao, Determining Precambrian crustal evolution in China: a case study from Wutaishan, Shanxi Province, demonstrating the application of precise SHRIMP U-Pb geochronology, J. Malpas, C.J.N. Fletcher, J.R. Ali, J.C. Aitchison, Editors, Aspects of the Tectonic Evolution of China. Geol. Soc. London Spec. Publ. 226 (2004), pp. 5-25. 
Wilde et al., 2004b S.A. Wilde, G.C. Zhao, K.Y. Wang and M. Sun, First SHRIMP zircon U$\mathrm{Pb}$ ages for the Hutuo Group in Wutaishan: further evidence for amalgamation of North China Craton. Chin. Sci. Bull., 49 (2004), pp. 83-90.

Wilde and Zhao, 2005 S.A. Wilde and G.C. Zhao, Archean to Paleoproterozoic evolution of the North China Craton. J. Asian Earth Sci., 24 (2005), pp. 519-522.

Wilde et al., 2005 S.A. Wilde, P.A. Cawood, K.Y. Wang and A. Nemchin, Granitoid evolution in the late Archean Wutai Complex, North China Craton. J. Asian Earth Sci., 24 (2005), pp. 597-613.

Wu and Zhong, 1998 C.H. Wu and C.T. Zhong, Early Proterozoic SW-NE collision model for the central part of the North China Craton: implications for tectonic regime of the khondalite downwar into lower crust in Jin-Meng high grade region, . Prog. Precambrian Res., 21 (1998), pp. 28-50 (in Chinese with English abstract).

Yang et al., 1988 Z.S. Yang, S.G. Li, B.X. Yu, D.H. Gao and C.Y. Gao, Structural deformation and mineralization in the Early Proterozoic Liao-Ji rock suite, eastern Liaoning Province, China. Precambrian Res., 39 (1988), pp. 31-38.

Yin et al., 2009 C.Q. Yin, G.C. Zhao, M. Sun, X.P. Xia, C.J. Wei, X.W. Zhou and W.H. Leung, LA-ICP-MS U-Pb zircon ages of the Qianlishan Complex: constrains on the evolution of the Khondalite Belt in the Western Block of the North China Craton. Precambrian Res., 174 (2009), pp. 78-94.

Yin et al., 2011 C.Q. Yin, G.C. Zhao, J.H. Guo, M. Sun, X.P. Xia, X.W. Zhou and C.H. Liu, $\mathrm{U}-\mathrm{Pb}$ and $\mathrm{Hf}$ isotopic study of zircons of the Helanshan Complex: constrains on the evolution of the Khondalite Belt in the Western Block of the North China Craton. Lithos, 122 (2011), pp. 25-38.

Yu et al., 1997 J.H. Yu, D.Z. Wang and C.Y. Wang, Geochemical characteristics and petrogenesis of the early proterozoic bimodal volcanic rocks from the Lüliang Group. Acta Petrol. Sin., 13 (1997), pp. 59-70.

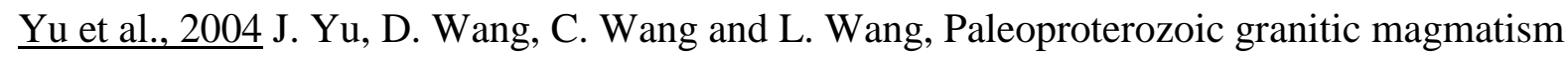
and metamorphism in Middle part of Lüliang range, Shanxi Province. Geol. J. China Univ., 10 (2004), pp. 500-512.

Zhai et al., 1992 M.G. Zhai, J.H. Guo and Y.H. Yan, Discovery and preliminary study of the Archean high-pressure granulites in the North China. Sci. China, 12B (1992), pp. 13251330.

Zhai and Santosh, 2011 M.G. Zhai and M. Santosh, The early Precambrian odyssey of the North China Craton: a synoptic overview. Gondwana Res., 20 (2011), pp. 6-25.

Zhai et al., 1995 M.G. Zhai, J.H. Guo, J.H. Li, Y.H. Yan, Y.G. Li and W.H. Zhang, The discovery of Archaean retrograde eclogites in the North China Craton. Chin. Sci. Bull., 40 (1995), pp. 1590-1594. 
Zhai et al., 2010 M.G. Zhai, T.S. Li, P. Peng, B. Hu, F. Liu and Y.B. Zhang, Precambrian key tectonic events and evolution of the North China Craton, T.M. Kusky, M.G. Zhai, W.J. Xiao, Editors, The Evolving Continents: Understanding Processes of Continental Growth. Geol. Soc. London Spec. Publ. 338 (2010), pp. 235-262.

Zhang et al., 2011 H.F. Zhang, M.G. Zhai, M. Santosh, C.R. Diwu and S.R. Li, Geochronology and petrogenesis of Neoarchean potassic meta-granites from Huai'an Complex: implications for the evolution of the North China Craton. Gondwana Res., 20 (2011), pp. 82-105.

Zhang et al., 1994 J.S. Zhang, H.G.M. Dirks and C.W. Passchier, Extensional collapse and uplift in a polymetamorphic granulite terrain in the Archean and Paleoproterozoic of north China. Precambrian Res., 67 (1994), pp. 37-57.

Zhang et al., 2006 J. Zhang, G.C. Zhao, M. Sun, S.A. Wilde, S.Z. Li and S.W. Liu, Highpressure mafic granulites in the Trans-North China Orogen: tectonic significance and age. Gondwana Res., 9 (2006), pp. 349-362.

Zhang et al., 2007 J. Zhang, G.C. Zhao, S.Z. Li, M. Sun, S.W. Liu, S.A. Wilde, A. Kröner and C.Q. Yin, Deformation history of the Hengshan Complex: implications for the tectonic evolution of the Trans-North China Orogen. J. Struct. Geol., 29 (2007), pp. 933-949.

Zhang et al., 2009 J. Zhang, G.C. Zhao, S.Z. Li, M. Sun, S.A. Wilde, S.W. Liu and C.Q. Yin, Polyphase deformation of the Fuping Complex, Trans-North China Orogen: structures, SHRIMP U-Pb zircon ages and tectonic implications. J. Struct. Geol., 31 (2009), pp. 177193.

Zhao, 2010 G.C. Zhao, Reply to the comment by Zhao et al. on: "Tectonic evolution of the Hengshan-Wutai-Fuping Complexes and its implication for the Trans-North China Orogen" [Precambrian Res. 170 (2009) 73-87]. Precambrian Res., 176 (2010), pp. 99-104.

Zhao et al., 1998 G.C. Zhao, S.A. Wilde, P.A. Cawood and L.Z. Lu, Thermal evolution of Archean basement rocks from the eastern part of the North China Craton and its bearing on tectonic setting. Int. Geol. Rev., 40 (1998), pp. 706-721.

Zhao et al., 1999a G.C. Zhao, S.A. Wilde, P.A. Cawood and L.Z. Lu, Thermal evolution of two textural types of mafic granulites in the North China Craton: evidence for both mantle plume and collisional tectonics. Geol. Mag., 136 (1999), pp. 223-240.

Zhao et al., 1999b G.C. Zhao, S.A. Wilde, P.A. Cawood and L.Z. Lu, Tectonothermal history of the basement rocks in the western zone of the North China Craton and its tectonic implications. Tectonophysics, 310 (1999), pp. 37-53.

Zhao et al., 1999c G.C. Zhao, P.A. Cawood and L.Z. Lu, Petrology and P-T history of theWutai amphibolites: implications for tectonic evolution of the Wutai Complex, China. Precambrian Res., 93 (1999), pp. 181-199.

Zhao et al., 2000a G.C. Zhao, P.A. Cawood, S.A. Wilde and L.Z. Lu, Metamorphism of basement rocks in the Central Zone of the North China Craton: implications for Paleoproterozoic tectonic evolution. Precambrian Res., 103 (2000), pp. 55-88. 
Zhao et al., 2000b G.-C. Zhao, S.A. Wilde, P.A. Cawood and L.-Z. Lu, Petrology and P-T-t path of the Fuping mafic granulites: implications for tectonic evolution of the central zone of the North China Craton. J. Metamorph. Geol., 18 (2000), pp. 375-391.

Zhao et al., 2001a G.C. Zhao, S.A. Wilde, P.A. Cawood and M. Sun, Archean blocks and their boundaries in the North China Craton: lithological, geochemical, structural and P-T path constraints and tectonic evolution. Precambrian Res., 107 (2001), pp. 45-73.

Zhao et al., 2001b G.C. Zhao, P.A. Cawood, S.A. Wilde and L.Z. Lu, High-pressure granulites (retrograded eclogites) from the Hengshan Complex North China Craton: petrology and tectonic implications. J. Petrol., 42 (2001), pp. 1141-1170.

Zhao et al., 2002a G.C. Zhao, P.A. Cawood, S.A. Wilde and M. Sun, Review of global 2.11.8 Ga orogens: implications for a pre-Rodinia supercontinent. Earth Sci. Rev., 59 (2002), pp. 125-162.

Zhao et al., 2002b G.C. Zhao, S.A. Wilde, P.A. Cawood and M. Sun, SHRIMP U-Pb zircon ages of the Fuping Complex: implications for late Archaean to Palaeoproterozoic accretion and assembly of the North China Craton. Am. J. Sci., 302 (2002), pp. 191-226.

Zhao et al., 2004a G.C. Zhao, M. Sun, S.A. Wilde and S.Z. Li, A Paleo-Mesoproterozoic supercontinent: assembly, growth and breakup. Earth Sci. Rev., 67 (2004), pp. 91-123.

Zhao et al., 2004b G.C. Zhao, M. Sun, S.A. Wilde and J.H. Guo, Late Archean to Palaeoproterozoic evolution of the Trans-North China Orogen: insights from synthesis of existing data from the Hengshan-Wutai-Fuping belt, J. Malpas, C.J.N. Fletcher, J.R. Ali, J.C. Aitchison, Editors, Aspects of the Tectonic Evolution of China. Geol. Soc. London Spec. Publ. 226 (2004), pp. 27-55.

Zhao et al., 2005 G.C. Zhao, M. Sun, S.A. Wilde and S.Z. Li, Late Archean to Paleoproterozoic evolution of the North China Craton: key issues revisited. Precambrian Res., 136 (2005), pp. 177-202.

Zhao et al., 2006 G.C. Zhao, M. Sun, Wilde, S.Z. Li, S.W. Liu and J. Zhang, Composite nature of the North China Granulite-Facies Belt: tectonothermal and geochronological constraints. Gondwana Res., 9 (2006), pp. 337-348.

Zhao et al., 2007 G.C. Zhao, A. Kroner, S.A. Wilde, M. Sun, S.Z. Li, X.P. Li, J. Zhang, X.P. Xia and Y.H. He, Lithotectonic elements and geological events in the Hengshan-WutaiFuping belt: a synthesis and implications for the evolution of the Trans-North China Orogen. Geol. Mag., 144 (2007), pp. 753-775.

Zhao et al., 2008 G.C. Zhao, S.A. Wilde, M. Sun, J.H. Guo, A. Kröner, S.Z. Li, X.P. Li and C.M. Wu, SHRIMP U-Pb zircon geochronology of the Huaian Complex: constraints on Late Archean to Paleoproterozoic crustal accretion and collision of the Trans-North China Orogen. Am. J. Sci., 308 (2008), pp. 270-303

Zhao et al., 2010 G.C. Zhao, S.A. Wilde, J.H. Guo, P.A. Cawood, M. Sun and X.P. Li, Single zircon grains record two Paleoproterozoic collisional events in the North China Craton. Precambrian Res., 177 (2010), pp. 266-276. 
Zheng et al., 2009 T.Y. Zheng, L. Zhao and R.X. Zhu, New evidence from seismic imaging for subduction during assembly of the North China Craton. Geology, 37 (2009), pp. 395-398 